\title{
Simulation of annual biogeochemical cycles of nutrient balance, phytoplankton bloom(s), and DO in Puget Sound using an unstructured grid model
}

\author{
Tarang Khangaonkar • Brandon Sackmann • \\ Wen Long • Teizeen Mohamedali • Mindy Roberts
}

Received: 13 December 2011 / Accepted: 9 July 2012 / Published online: 14 August 2012

(C) The Author(s) 2012. This article is published with open access at Springerlink.com

\begin{abstract}
Nutrient pollution from rivers, nonpoint source runoff, and nearly 100 wastewater discharges is a potential threat to the ecological health of Puget Sound with evidence of hypoxia in some basins. However, the relative contributions of loads entering Puget Sound from natural and anthropogenic sources, and the effects of exchange flow from the Pacific Ocean are not well understood. Development of a quantitative model of Puget Sound is thus presented to help improve our understanding of the annual biogeochemical cycles in this system using the unstructured grid FiniteVolume Coastal Ocean Model framework and the Integrated Compartment Model (CE-QUAL-ICM) water quality kinetics. Results based on 2006 data show that phytoplankton growth and die-off, succession between two species of algae, nutrient dynamics, and dissolved oxygen in Puget Sound are strongly tied to seasonal variation of temperature, solar radiation, and the annual exchange and flushing induced by upwelled Pacific Ocean waters. Concentrations in the mixed outflow surface layer occupying approximately 5-20 $\mathrm{m}$ of the upper water column show strong effects of eutrophication from natural and anthropogenic sources, spring and summer algae blooms, accompanied by depleted
\end{abstract}

Responsible Editor: Nadia Pinardi

This article is part of the Topical Collection on Multi-scale modelling of coastal, shelf and global ocean dynamics

T. Khangaonkar $(\bowtie) \cdot$ W. Long

Marine Sciences Division, Pacific Northwest National Laboratory,

1100 Dexter Avenue North, Suite 400,

Seattle, WA 98109, USA

e-mail: tarang.khangaonkar@pnnl.gov

B. Sackmann $\cdot$ T. Mohamedali $\cdot$ M. Roberts

Washington State Department of Ecology,

PO Box 47600, Olympia, WA 98504-7600, USA nutrients but high dissolved oxygen levels. The bottom layer reflects dissolved oxygen and nutrient concentrations of upwelled Pacific Ocean water modulated by mixing with biologically active surface outflow in the Strait of Juan de Fuca prior to entering Puget Sound over the Admiralty Inlet. The effect of reflux mixing at the Admiralty Inlet sill resulting in lower nutrient and higher dissolved oxygen levels in bottom waters of Puget Sound than the incoming upwelled Pacific Ocean water is reproduced. By late winter, with the reduction in algal activity, water column constituents of interest, were renewed and the system appeared to reset with cooler temperature, higher nutrient, and higher dissolved oxygen waters from the Pacific Ocean.

Keywords Biogeochemical model $\cdot 3$-D hydrodynamic model $\cdot$ Nutrients $\cdot$ Dissolved oxygen · Phytoplankton · Algae $\cdot$ Unstructured grid · FVCOM · CE-QUAL-ICM · Fjords $\cdot$ Puget Sound $\cdot$ Salish Sea

\section{Introduction}

The Puget Sound, Strait of Juan de Fuca, and Georgia Strait, recently defined as the Salish Sea, compose a large and complex estuarine system in the Pacific Northwest portion of the U.S.A. and adjacent Canadian waters [see Fig. 1a]. A model study of the Salish Sea was conducted with a focus on the Puget Sound region in an effort to improve our understanding of the annual biogeochemical cycles of nutrient loading and consumption by algal growth and the effects of seasonal variations on primary productivity and dissolved oxygen (DO). Pacific tides propagate from the west into the system via the Strait of Juan de Fuca around the San Juan Islands, north into Canadian waters through the 
Georgia Strait. Propagation of tides into Puget Sound occurs primarily through Admiralty Inlet. Significant nutrient fluxes reach Puget Sound waters through rivers, runoff from watersheds, wastewater treatment outfalls, and are considered a potential pollution threat to Puget Sound water quality and ecological health. This is especially true of the poorly flushed bays and inlets in the southern ends of Puget Sound where surface nitrates may be depleted in the summer with high levels of algae, and DO often reaching critical levels near the seabed. Harrison et al. (1994) pointed out that although the main basin of Puget Sound is well supplied with natural deepwater nutrient loads from the Strait of Juan de Fuca and the Pacific Ocean, some of the poorly flushed basins are showing signs of eutrophication. In the spring and summer, Puget Sound regularly experiences algae blooms, during which nutrient concentrations drop to near zero levels in the surface layers, suggesting nutrient limitation in several basins (e.g., Thom et al. 1988; Thom and Albright 1990; Bernhard and Peele 1997; Newton et al. 1995, 1998; Newton and Van Voorhis 2002).

In many coastal plain estuaries, dominant nutrient fluxes through the coastal zone are often from the open ocean with little evidence of impacts from anthropogenic perturbation (Jickells 1998). Large quantities of nutrient loads from the Pacific Ocean also enter the Salish Sea through the Strait of Juan de Fuca and enter Puget Sound through tidal exchange flow over the Admiralty Inlet (Harrison et al. 1994). The transport and mixing of this inflow is controlled by complex 3-D baroclinic circulation processes. Based on review of historic current meter records, Ebbesmeyer and Barnes (1980) developed a conceptual model of Puget Sound that describes circulation in the main basin of Puget Sound as that in a fjord with deep sills (landward sill zone at Tacoma Narrows and a seaward sill zone at Admiralty Inlet) defining a large basin, outflow through the surface layers, and inflow at depth. Recent numerical model-based analyses confirm this conceptual model and demonstrate that circulation characteristics in Puget Sound vary from that of a partially mixed estuary in some subbasins to distinctly fjord like in others (Khangaonkar et al. 2011; Sutherland et al. 2011) with long residence times. The tidally averaged marine flow (estuarine exchange flow) which enters Puget Sound through the lower part of the water column over the Admiralty Sill $\left(10-20 \times 10^{3} \mathrm{~m}^{3} / \mathrm{s}\right)$ (Cokelet et al. 1990 and Babson et al. 2006) is nearly 10-20 times the average freshwater river inflow to Puget Sound basin which was $1.348 \times 10^{3} \mathrm{~m}^{3} / \mathrm{s}$ in 2006). Primary productivity and annual nutrient consumption tied to algal blooms is restricted to the shallow brackish outflow layer, which varies between $10-25 \%$ of the water column through most of Puget Sound. In some of the shallow subbasins, this surface algal production contributes to DO levels that exceed $10 \mathrm{mg} / \mathrm{L}$, sometimes reaching supersaturated levels. But some areas of Puget Sound with restricted water exchange such as Hood Canal and South Puget Sound with long residence times have experienced hypoxia and could be vulnerable to further increases in nutrient loading (Albertson et al. 2002; Newton et al. 2007) despite the large exchange with the Pacific Ocean.

Prior efforts to develop quantitative models of the biogeochemical processes in Puget Sound have been limited. One of the earliest efforts to quantify the relationship between the growth of phytoplankton and climatic conditions and circulation was by Winter et al. (1975). Using approximate circulation analysis and simplified formulation of phytoplankton kinetics, they demonstrated that phytoplankton growth in Puget Sound is closely coupled to the seasonal variation and circulation characteristics. Subsequent Puget Sound-wide model development efforts have ranged from simplified box models (Friebertshauser and Duxbury 1972; Hamilton et al. 1985; Li et al. 1999; Cokelet et al. 1990; Babson et al. 2006) to vertical 2-D models (Lavelle et al. 1991) to fully 3-D baroclinic numerical models (Khangaonkar et al. 2011; Sutherland et al. 2011; Yang and Khangaonkar 2010; Nairn and Kawase 2002). However, these studies have focused on hydrodynamics and physical processes only. The Washington State Department of Ecology has developed a biogeochemical model of South Puget Sound to simulate DO in response to phytoplankton primary production, oxidation of organic material, and sediment flux (Roberts et al. 2009). Similarly, the University of Washington (UW) has developed a model of Hood Canal in connection with hypoxia concerns as part of the Hood Canal Dissolved Oxygen Program (Bahng et al. 2007). However, modeling studies of this nature, covering the entire Puget Sound and the Salish Sea domain are sparse.

In this paper, we present the first 3-D water quality model of the entire Salish Sea with a focus on the Puget Sound region. Recognizing the importance of circulation and tidal flushing, a previously established hydrodynamic model of the Salish Sea (Khangaonkar et. al 2011) was linked to a carbon-based biogeochemical model (Cerco and Cole 1994) for simulating eutrophication and algal kinetics. A total of 19 state variables, including two species of algae, dissolved and particulate carbon, and nutrients, were simulated as part of the carbon cycle to calculate algal production and decay and the impact on DO. Preliminary calibration of the model to measured phytoplankton (chlorophyll $a$ ), nutrients, and DO data in Puget Sound are presented for the year 2006. To properly incorporate the role played by anthropogenic loads, all known sources of nutrients such as rivers, nonpoint source runoff from watersheds, and wastewater outfalls were characterized through hydrologic analysis and included in the computation. We then present a comparison of model results to observed data and provide a discussion of our improved understanding of the biogeochemistry of this system. 


\section{Model description and configuration}

The combined model was constructed using the unstructured grid finite-volume coastal ocean model (FVCOM) framework and the integrated compartment model (CE-QUAL-ICM) biogeochemical water quality kinetics. Use of the unstructured grid framework was driven by the need to accommodate complex shoreline geometry, waterways, and islands in Salish Sea. The water quality computations were conducted offline using a previously computed hydrodynamic solution over the same model grid. The hydrodynamic model of Puget Sound at two separate grid resolutions has been discussed in detail previously (Khangaonkar et al. 2011; Khangaonkar and Yang 2011; Yang and Khangaonkar 2010) and is presented here in a summary form. In this paper, we focus on the aspects of model setup related to estimates of loads to the system from various rivers, streams, and wastewater sources, and the biogeochemical configuration of the model.

\subsection{Hydrodynamic model}

The hydrodynamic model of Salish Sea uses FVCOM, which was developed at the University of Massachusetts (Chen et al. 2003). FVCOM is a 3-D hydrodynamic model that can simulate tidally and density-driven, and meteorological forcinginduced circulation in an unstructured, finite element framework. Figure $1 \mathrm{~b}$ shows the unstructured model grid constructed using triangular cells with higher resolution in narrower regions of the Salish Sea, growing coarser in the Strait of Juan de Fuca with up to 3-km resolution near the open boundary. The grid resolution is on average $250 \mathrm{~m}$ in the inlets and bays and approximately $800 \mathrm{~m}$ inside the Puget Sound main basin. The model domain comprises the entire Salish Sea including the Puget Sound and the Strait of Juan de Fuca, Haro Strait, Georgia Strait, and San Juan Islands. The ocean-side open boundary is located just west of the Strait of Juan de Fuca, while the second open boundary is located near the northernmost point of the Georgia Strait (Canadian waters) near Johnstone Strait. The model uses the Smagorinsky scheme for horizontal mixing (Smagorinsky 1963) and the Mellor-Yamada level 2.5 turbulent closure scheme for vertical mixing (Mellor and Yamada 1982). Bottom stress is computed using a drag coefficient assuming a logarithmic boundary layer over a bottom roughness height $Z_{0}$ of $0.001 \mathrm{~m}$.

The model grid consists of 9,013 nodes and 13,941 elements and uses a mode splitting numerical approach to solve the governing equations in depth-averaged 2-D barotropic external mode and 3-D baroclinic internal mode. A time step of $2 \mathrm{~s}$ was used for the external barotropic mode and $10 \mathrm{~s}$ for the internal mode. A sigma-stretched coordinate system was used in the vertical plane with ten terrain-following sigma layers distributed using a power law function with exponent $P$-Sigma $=1.5$ with more layer density near the surface. This scale and the selected time step(s) allow sufficient resolution of the various major river estuaries and subbasins while allowing year-long simulation within $18 \mathrm{~h}$ of run time on a 40 processor cluster computer. The bathymetry was derived from a combined data set consisting of data from the Puget Sound digital elevation model from University of Washington and data provided by the Department of Fisheries and Oceans Canada (DFO) covering the Georgia Strait. The bathymetry was smoothed to minimize hydrostatic inconsistency associated with the use of the sigma coordinate system with steep bathymetric gradients. The associated slope-limiting ratio $\delta H / H=0.1$ to 0.2 was specified within each grid element following guidance provided by Mellor et al. (1994) and using site-specific experience from Foreman et al. (2009), where $H$ is the local depth at a node and $\delta H$ is change in depth to the nearest neighbor. The smoothing procedure also includes adjustment of bathymetry applied to depths greater than $50 \mathrm{~m}$ to ensure that the individual basin and the total domain volumes remained with $1 \%$ of the original values.

The model is forced by tides specified along the open boundaries using harmonic tide predictions (Flater 1996), freshwater inflow, and wind and heat flux at the water surface. The meteorological parameters were obtained from the Weather Forecasting Research (WRF) model reanalysis data generated by the University of Washington. Available WRF data were on a coarse $12-\mathrm{km}$ grid and required a $20 \%$ reduction of net heat flux to account for different albedo over land vs. water, as part of calibration of water surface temperatures. Temperature and salinity profiles along the open boundaries were specified based on monthly observations conducted by DFO (near the open boundaries). Originally, the model included 19 gaged rivers that are incorporated with the resolution of estuarine reaches. As part of the biogeochemical model development effort, additional freshwater sources in the form of 45 nonpoint source loads and 99 wastewater treatment plant discharges were added to the model. The freshwater inflow to the domain estimated through hydrologic modeling analysis is presented in the next section. Approximately $34 \%$ of this inflow is from watersheds that drain into Puget Sound south of Admiralty Inlet, and $64 \%$ is from watersheds that drain into Georgia Strait Basin in Canadian reaches. Hydrodynamic model error statistics for water surface elevation, velocity, salinity, and temperature were regenerated to ensure that the overall model performance quality was retained (see "Appendix", Tables A1, A2, and A3)

Of importance to biogeochemical computations in Puget Sound is the ability of the model to simulate tidal residual inflow, and bottom water renewal reasonably. In well-mixed estuaries, flushing time (defined as the ratio of basin volume to net inflow) offers a first order comparison to time scales of biogeochemical processes. However in highly stratified estuaries with interconnected basins such as Puget Sound, residence time calculated using a tracer or lagrangian particles provides a more accurate measure. Figure 2 shows 


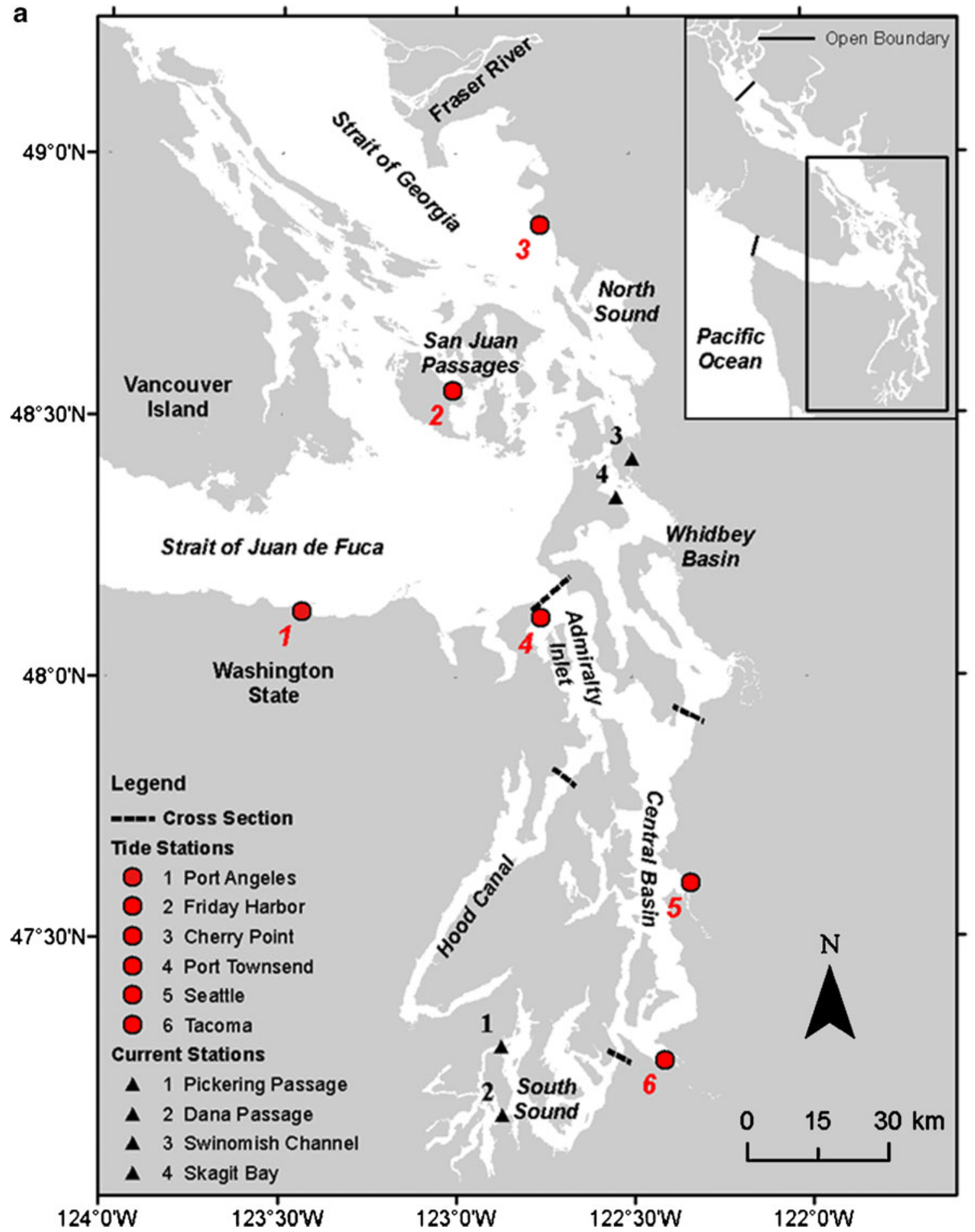

Fig. 1 a Oceanographic regions of Puget Sound and the Northwest Straits (Salish Sea) including the inner subbasins-Hood Canal, Whidbey Basin, Central Basin, and South Sound. b Intermediate-scale finite volume FVCOM model grid along with water-quality monitoring stations

plots of mean annual inflows and outflows computed at selected sections in the basin from the year 2006 solution and shows characteristic features such as inflow at depth and outflow through the mixed near-surface layers. Computed tidally averaged inflows to various basins are listed in Table 1. Also shown in Table 1 are computed "e-folding" residence times for each basin, defined as the time taken for the initial concentration in the individual basins (1 unit) to dilute to 1/e level over the water column. For this analysis, the constituent was introduced into the domain after a spin-up period of 1 year and allowed to flush out. For the year 2006, the computed tidally averaged inflow rate of $17 \times 10^{3} \mathrm{~m}^{3} / \mathrm{s}$ over Admiralty 
b

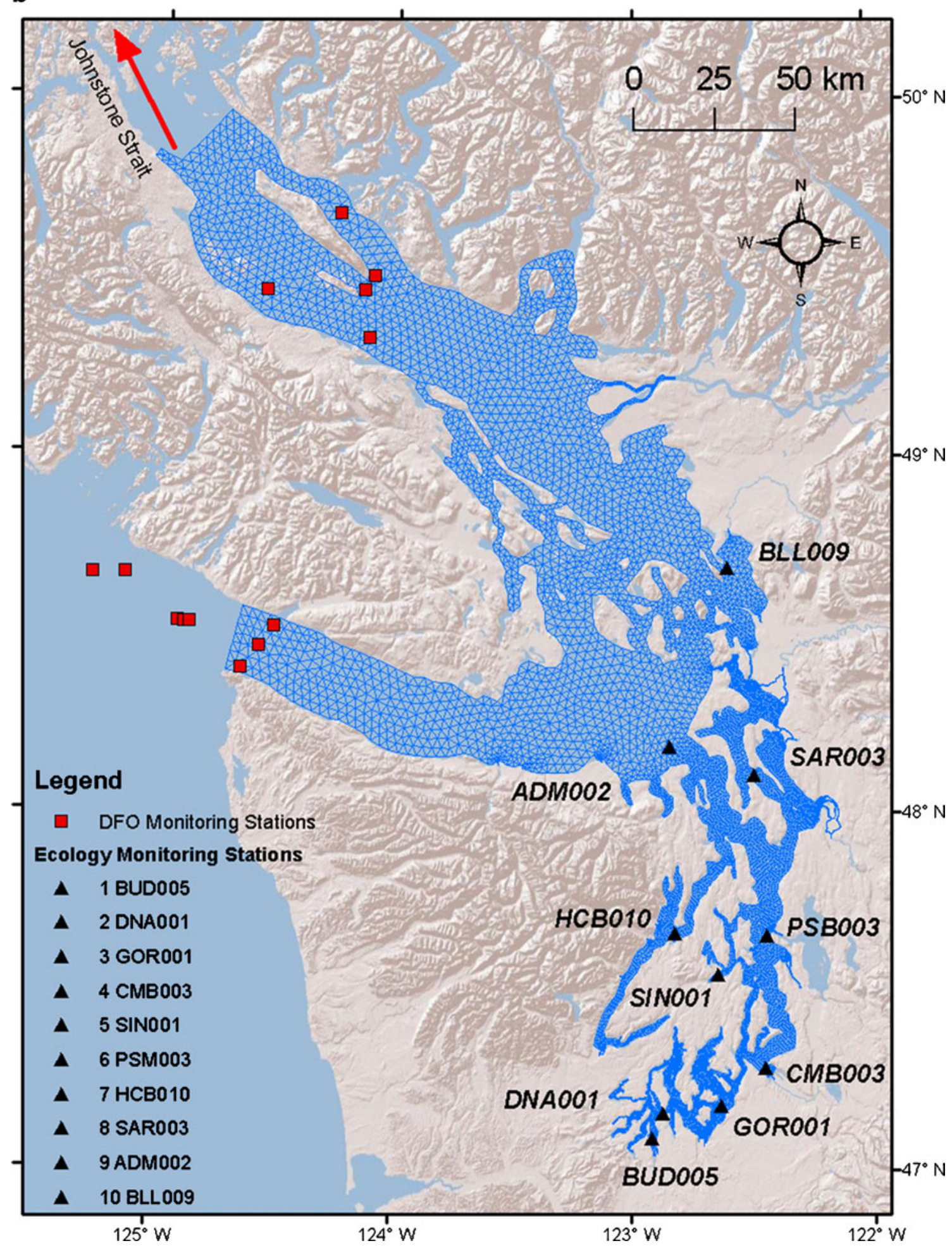

Fig. 1 (continued)

Inlet to Puget Sound is in the range of $10-20 \times 10^{3} \mathrm{~m}^{3} / \mathrm{s}$ reported in literature (Cokelet et al. 1990; Babson et al. 2006; Sutherland et al. 2011). The results show that inner basins such as Hood Canal and South Puget Sound, sheltered behind their individual sills, have the largest residence times.
2.2 Inflows and nutrient loads

The U.S. Geological Survey (USGS) and Water Survey of Canada (WSC) maintain continuous gages on several streams and most large rivers within the Puget Sound area. 

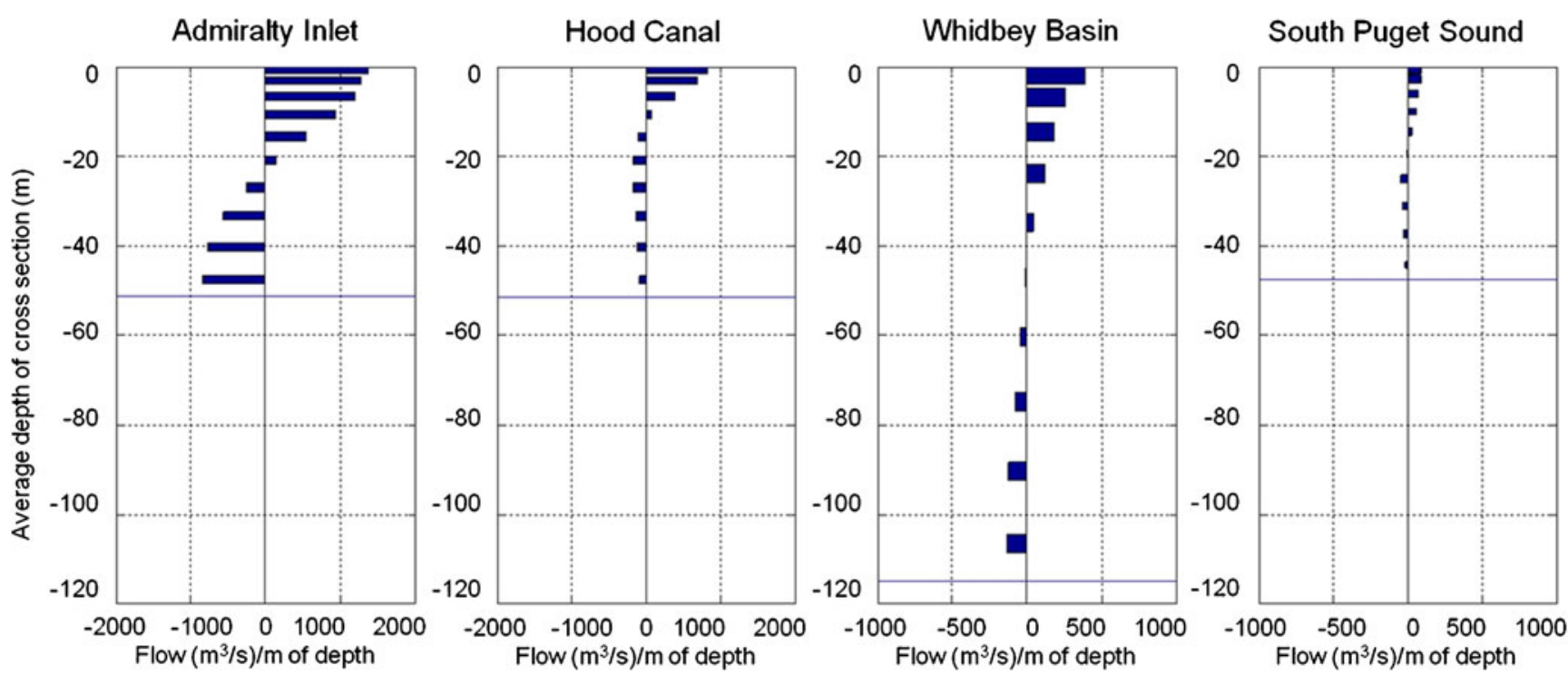

Fig. 2 Mean annual flow per meter of water depth across selected cross sections of the year 2006 model simulation. Positive values indicate seaward outflow and negative values represent landward inflow to the basins

Permanent USGS gaging stations capture approximately $69 \%$ of the watershed tributary to the main study area, which includes all watersheds tributary to Puget Sound. For rivers and streams that had USGS or WSC gaging station records within their watershed, flow estimates were retrieved and extrapolated to the mouth of the watershed by scaling streamflow by the larger watershed area and average annual rainfall. While the ungaged area is relatively small, streamflow for these areas was also estimated so that all surface water inputs were explicitly included. First, we identified the nearest continuously gaged stations in watersheds of similar size, land use, and proximity. Next, we normalized this continuous streamflow record by drainage area and average annual rainfall. Finally, we scaled the normalized streamflow by the area and average annual rainfall of the target watershed. The same approach was applied to watersheds with no primary stream inflow point. Figure 3 shows a total of 64 watershed areas that drain into the Salish Sea, including regions of interest in Puget Sound and
Georgia Strait. A detailed description of the hydrologic analysis used to develop the streamflows is provided by Mohamedali et al. (2011).

Nutrient measurements from a variety of sources were used to develop watershed-loading estimates for the 64 watersheds of interest. The primary source of the data was measurements conducted as part of the Washington State Department of Ecology's South Puget Sound Dissolved Oxygen study, which monitored 33 rivers between 2006 and 2007 (Roberts et al. 2008). Multiple linear regression was used to predict daily nutrient concentrations for the rivers and streams from more coarsely sampled (e.g., monthly) data sets. The approach related nutrient concentrations to flow patterns and time of year and provided a best-fit to available monitoring data.

$$
\begin{gathered}
\log (C)=b_{0}+b_{1} \log (Q / A)+b_{2}[\log (Q / A)]^{2}+ \\
b_{3} \sin \left(2 \pi f_{y}\right)+b_{4} \cos \left(2 \pi f_{y}\right)+b_{5} \sin \left(4 \pi f_{y}\right)+ \\
b_{6} \cos \left(4 \pi f_{y}\right)
\end{gathered}
$$

Table 1 Mean annual inflows to Salish Sea and Puget Sound subbasins along with residence times estimated for selected locations from analysis of the year 2006 model simulation

\begin{tabular}{lclc}
\hline Subbasin and reach & $\begin{array}{l}\text { Mean annual } \\
\text { tidal inflow }\left(\mathrm{m}^{3} / \mathrm{s}\right)\end{array}$ & Station name & $\begin{array}{c}\text { Residence } \\
\text { time (days) }\end{array}$ \\
\hline Strait of Juan de Fuca & 129,300 & Pillar Point & 61 \\
Admiralty Inlet to Puget Sound & 17,117 & Admiralty Inlet & 160 \\
Main Basin -Puget Sound & 12,051 & Jefferson Point & 257 \\
Whidbey Basin (inflow through & 6,111 & Saratoga Passage & 228 \\
$\quad$ Possession Sound) & 5,066 & Eldon Point & 282 \\
Hood Canal (inflow over the sill) & 814 & Devils Head & 292 \\
South Puget Sound & & & \\
(inflow over Tacoma Narrows sill) & & & \\
\hline
\end{tabular}



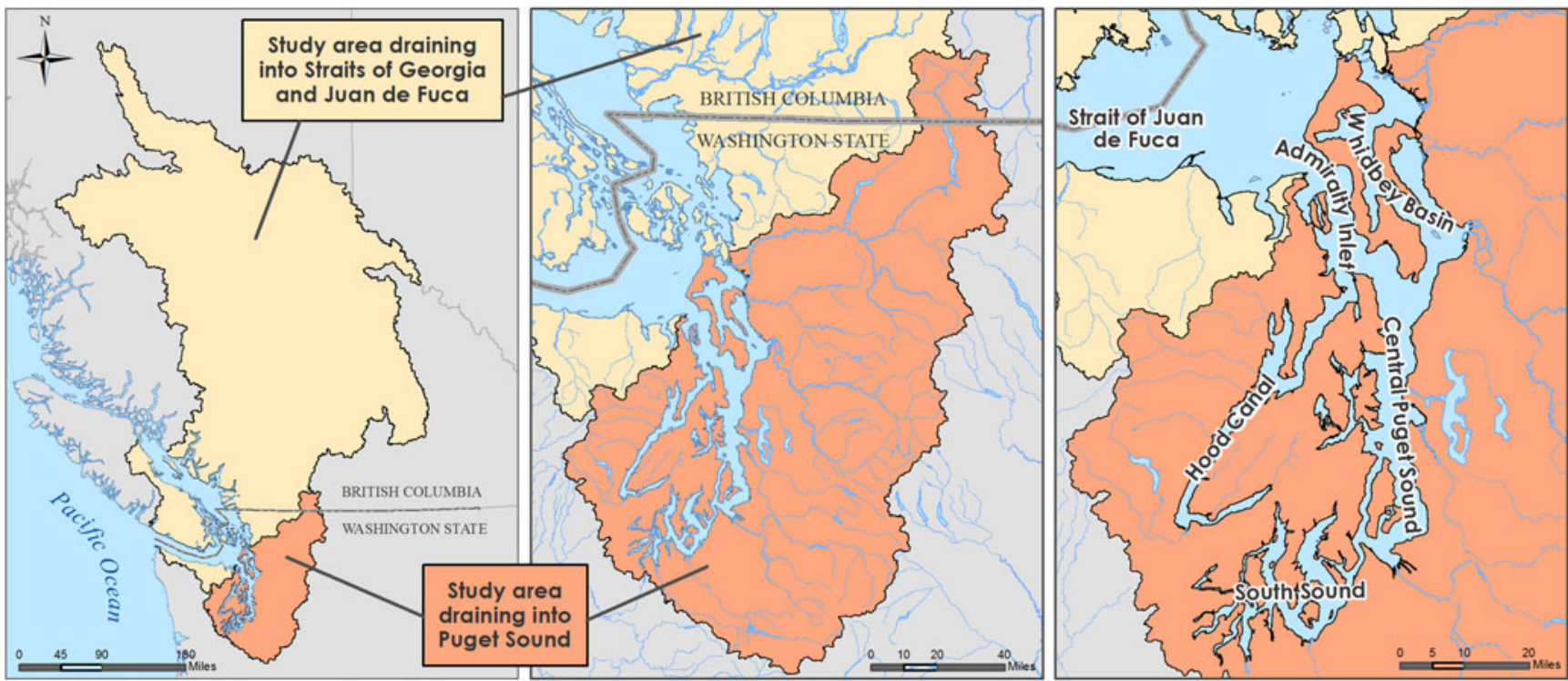

Fig. 3 The primary area of interest includes the watersheds that drain into Puget Sound, but watersheds that drain into the Straits of Georgia and Juan de Fuca have also been included

where $C$ is the observed parameter concentration (milligrams per liter), $Q$ is streamflow (cubic meter per second), $A$ is the area drained by the monitored location (square kilometer), $f_{\mathrm{y}}$ is the year fraction (dimensionless, varies from 0 to 1$)$, and $b_{i(i=1,6)}$ are the best-fit regression coefficients.

Of the 64 watersheds within the study domain, 35 stations had sufficient water-quality monitoring data available to calculate regression coefficients. For the 29 watersheds that did not have a primary source of water-quality data, we applied regression coefficients from the most appropriate nearby watershed for which regression results were available. Because monitoring did not always occur during the largest flow event, the regression model tends to extrapolate patterns at higher flows. To minimize the error caused by extrapolation, the minimum and maximum concentrations recorded in the monitoring data were used to constrain predicted concentrations for all parameters. A smearing adjustment was then applied to correct for bias due to retransformation from log space (Cohn et al. 1992). Daily loads from rivers and streams were calculated as a simple product of streamflow and nutrient concentration.

Ninety-nine municipal wastewater treatment plants (WWTPs) or industrial facilities discharge to the model domain, either directly into the marine waters of Puget Sound or into rivers downstream of monitoring locations. This includes 78 U.S. municipal WWTPs, 9 Canadian municipal WWTPs, 5 oil refineries, 4 active pulp/paper mills, and 1 aluminum facility within the Puget Sound study area. Seventeen WWTPs in south and central Puget Sound were monitored over 15 months between August 2006 and October 2007. Monitoring data and a multiple linear regression technique, similar to what was outlined above for watersheds, were used to estimate monthly nutrient concentrations for the 17 WWTPs for the years 1999 through 2008. Unlike rivers and streams, WWTP flows and concentrations do not vary greatly from day-to-day and the use of constant monthly values is appropriate to represent WWTP variability. The effluent flow rates influenced nitrogen levels with the lowest concentrations in the smallest plants and the highest concentrations in the largest plants. For the WWTPs that had limited or no data where plant-specific regression coefficients could not be developed, the effluent concentrations specified were the group average concentrations based on plant size divided in to three size classes: large (>10 MGD), medium (4-10 MGD), and small $(<4$ MGD) based on design flows in the permits.

Of all the forms of nitrogen, dissolved inorganic nitrogen (DIN; sum of nitrate+nitrite and ammonium) is of greatest interest because this form of nitrogen often limits growth of marine algae. Figure 4 is an example of computed loads distributed around the Salish Sea domain computed using this technique. Median DIN concentrations in rivers and WWTPs discharging directly into the Salish Sea between 1999 and 2008 are shown. Figure 5a shows a summary of river discharge constituents for the year 2006 for 19 permanently gaged rivers. Figure $5 \mathrm{~b}$ shows a summary of major WWTPs (>10 MGD) discharge constituents. Daily flow and concentration values were specified for all constituents for all river, point, and nonpoint sources.

Although formal uncertainty analysis on these estimates was not attempted, an assessment of how well the multiple linear regression method performed was done by (1) visually comparing plots of observed vs. predicted concentrations, (2) evaluating the significance of the multiple linear 

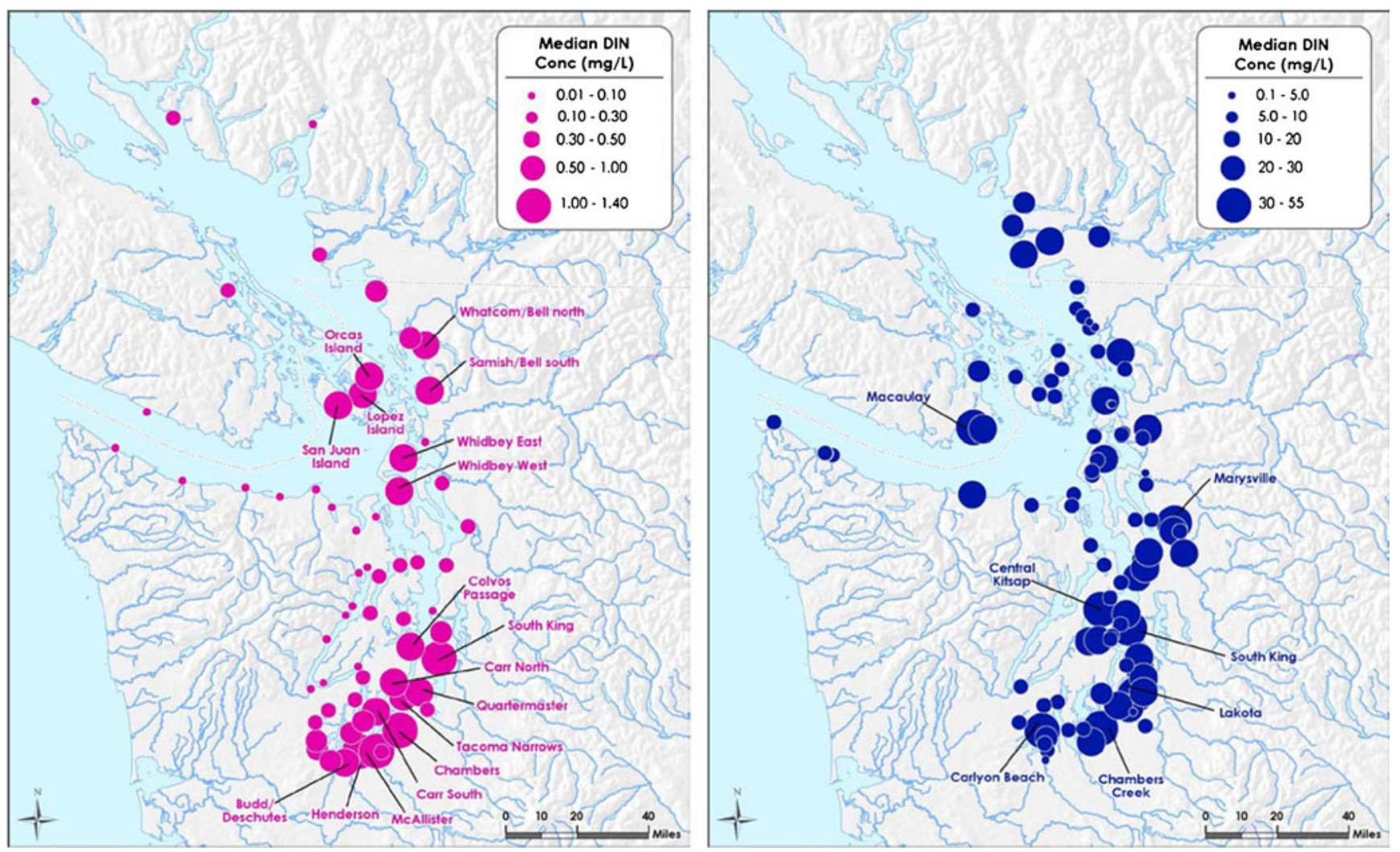

Fig. 4 Median river (left) and WWTP (right) dissolved inorganic nitrogen (DIN) concentrations for 1999 to 2008

regression coefficients, and (3) calculating the adjusted $R^{2}$ values for the multiple linear regression (see Mohamedali et al. 2011). Sources of uncertainty include (a) the sinusoidal function in the multiple linear regression method which captures seasonality, (b) uncertainty in observed/measured flow data, and (c) uncertainty in observed/measured concentration data used to estimate the regression coefficients. Multiple linear regression relationships developed for nitrate+nitrite (which makes up the largest proportion of DIN concentrations in rivers) had significant relationships in $94 \%$ of watersheds, with a median adjusted $R^{2}$ value of 0.81 across all watersheds. Though streamflow and seasonality are major drivers that determine in-stream DIN concentrations, the multiple linear regression method may not capture the effect of individual storms or other unique flow events on concentrations. Though the uncertainty is likely larger in watersheds where we did not have observed concentration data, these watersheds are small, and contribute much smaller volumes of water to Puget Sound. The watersheds of the 35 rivers for which we developed site-specific multiple linear regressions (i.e., regressions that were developed from observed data collected within those watersheds) cover $80 \%$ of the total watershed area tributary to the U.S. portions of the Salish Sea. WWTPs have much less variability in concentrations over time within a single plant, and more variability between plants. When evaluating WWTP data, we noticed patterns in concentrations between plant sizes, which is why we grouped plants into small, medium, and large plants. In total, the 17 WWTPs for which we developed multiple linear regressions based on plantspecific data contribute $79 \%$ of the total WWTP average annual DIN loading and $60 \%$ of the total WWTP flow volume to these waters.

\subsection{Biogeochemical model}

We selected the "offline" approach of coupling a FVCOM hydrodynamic solution to an unstructured biogeochemical model. The water-quality calculations in this mode are conducted using a previously computed hydrodynamic solution. The offline coupling provides the benefit of computational efficiency where the burden of repeating hydrodynamic computations for sensitivity tests in the same hydrodynamic flow field is avoided. The associated storage of large solution files is progressively becoming less of a concern with improvements in technology. The biogeochemical model selected for use with the FVCOM solution was CEQUAL-ICM, a 3-D, time variable, integrated-compartment model, developed by the U.S. Army Corps of Engineers for simulating water quality (Cerco and Cole 1994). CEQUAL-ICM was originally developed as the eutrophication model for the Chesapeake Bay and has been applied to a 
number of lakes and estuaries (e.g., Bunch et al. 2000; Cerco et al. 2000, 2004; Cerco 2000; Tillman et al. 2004). The model is capable of simulating 32 state variables, including multiple algae, carbon, multiple zooplankton, phosphorus, nitrogen, silica, and DO. Aquatic vegetation, benthic deposit feeders, and a predictive sub-model to calculate the interactive fluxes of DO and nutrients between the sediment and the water columns are also incorporated. The use of the carbon cycle as the basis for eutrophication calculations, the ability to include sediment diagenesis, and the use of a finite volume approach were important considerations in selection of CE-QUAL-ICM for the Salish Sea model development with FVCOM.

The kinetics simulated by the model are described in detail in Cerco and Cole (1995) and briefly summarized here as used for the Salish Sea model. For this calibration effort, we included the following 19 state variables:

- Algae species 1-diatoms

- Algae species 2-dinoflagellates

- Dissolved organic carbon (DOC) - labile

- DOC-refractory

- Particulate organic carbon (POC) - labile

- POC-refractory

- Ammonium $\left(\mathrm{NH}_{4}\right)$

- Nitrate+nitrite $\left(\mathrm{NO}_{3}+\mathrm{NO}_{2}\right)$

- Dissolved organic nitrogen (DON)-labile

- DON-refractory

- Particulate organic nitrogen (PON)-labile

- PON—refractory

- Phosphate $\left(\mathrm{PO}_{4}\right)$

- Dissolved organic phosphorus (DOP)-labile

- DOP-refractory

- Particulate organic phosphate (POP)_labile

- POP-refractory

- Particulate inorganic phosphate

- DO.

The organic carbon cycle in the model comprises phytoplankton production and excretion, predation on phytoplankton by zooplankton, dissolution of particulate carbon, heterotrophic respiration, denitrification, and settling. Carbon, as a representative currency in the model, is incorporated into phytoplankton biomass, and algal production is the primary source of carbon in the model. The change in biomass at each time step is computed using the specific growth rate of each phytoplankton, which is converted into a primary production rate from the phytoplankton-specific carbon to chlorophyll ratio.

Nutrient concentrations, light intensity, and temperature within the water column determine the growth rate used in the above calculations. Silica concentrations, which also affect growth rates, were not explicitly simulated because silica is not considered a factor limiting growth rate in Puget Sound.
The calculated change in phytoplankton carbon-based biomass is then reallocated into zooplankton biomass, using the calculated grazing and growth rates for zooplankton (in the simulations described here, however, zooplanktons were not simulated explicitly but zooplankton grazing was included in the form of first order decay rate as a simplification). Grazed material is converted using the appropriate pathways into dissolved and particulate inorganic carbon, nitrogen, and phosphorus. Losses due to predation and excretion are divided into labile and refractory pools of dissolved and particulate organic carbon. Through hydrolysis, particulate organic carbon is converted into dissolved forms. The remaining particulate matter settles to sediment. From each carbon pool, nutrient pools are calculated using the ratios of nitrogen and phosphorus, to carbon. Loss rates from nutrient pools represent uptake by phytoplankton. Sinking of phytoplankton redistributes phytoplankton throughout the water column. Diel vertical migration driven by light through specification of negative settling rates for each species is also feasible.

Phytoplankton growth is predicated on nutrient and light availability in the water column and temperature. The growth limitation of algae can be through "Liebig's law of the minimum" (Odum 1971), where either light or one major nutrient can limit growth. In this current configuration of the model, Michaelis-Menten kinetics (e.g., Eppley et al. 1969) were used to determine nutrient limitation for DIN, $\mathrm{NH}_{4}$, and $\mathrm{PO}_{4}$ while the square root formula was used for light limitation (Jassby and Platt 1976). Although preference for reduced forms of nitrogen is encoded in the model, suppression of growth rates of phytoplankton by the presence of ammonium is not considered. Light in the water column is attenuated through scattering and absorption by constituents in the water column, including chlorophyll $a$. Spectral absorption was used in the model, but only a generalized chlorophyll $a$ based spectrum was used, due to limited available data for Puget Sound. Temperature limitation on growth is incorporated through the specification of optimum temperature for growth of each species of algae.

Nitrogen fluxes include nitrification, denitrification, benthic flux rates, conversion of algal material into dissolved and particulate organic forms, and boundary loads. Similarly, phosphate fluxes include transformations of algal material and boundary fluxes. Dissolved oxygen is affected by saturation state (calculated from salinity and temperature), reaeration due to wind stress, algal photosynthesis and respiration, nitrification, heterotrophic respiration, and sediment oxygen demand. Organic carbon concentrations (particulate and dissolved, refractory and labile) are calculated from algal production and excretion, predation of algae and carbon kinetics (dissolution of particulate organic carbon, heterotrophic respiration, and settling). In CE-QUAL-ICM, all organic matter entering the model domain from the open boundaries and 
Fig. 5 a River discharge constituents, year 2006 average - ammonia, N; (nitrate + nitrite-N); phosphate, $\mathrm{P}$; DOC, DON, DOP, and flow. b Wastewater treatment plant discharge constituents, year 2006 average - ammonia, (nitrate + nitrite), phosphate, DOC, DON, DOP, and flow a
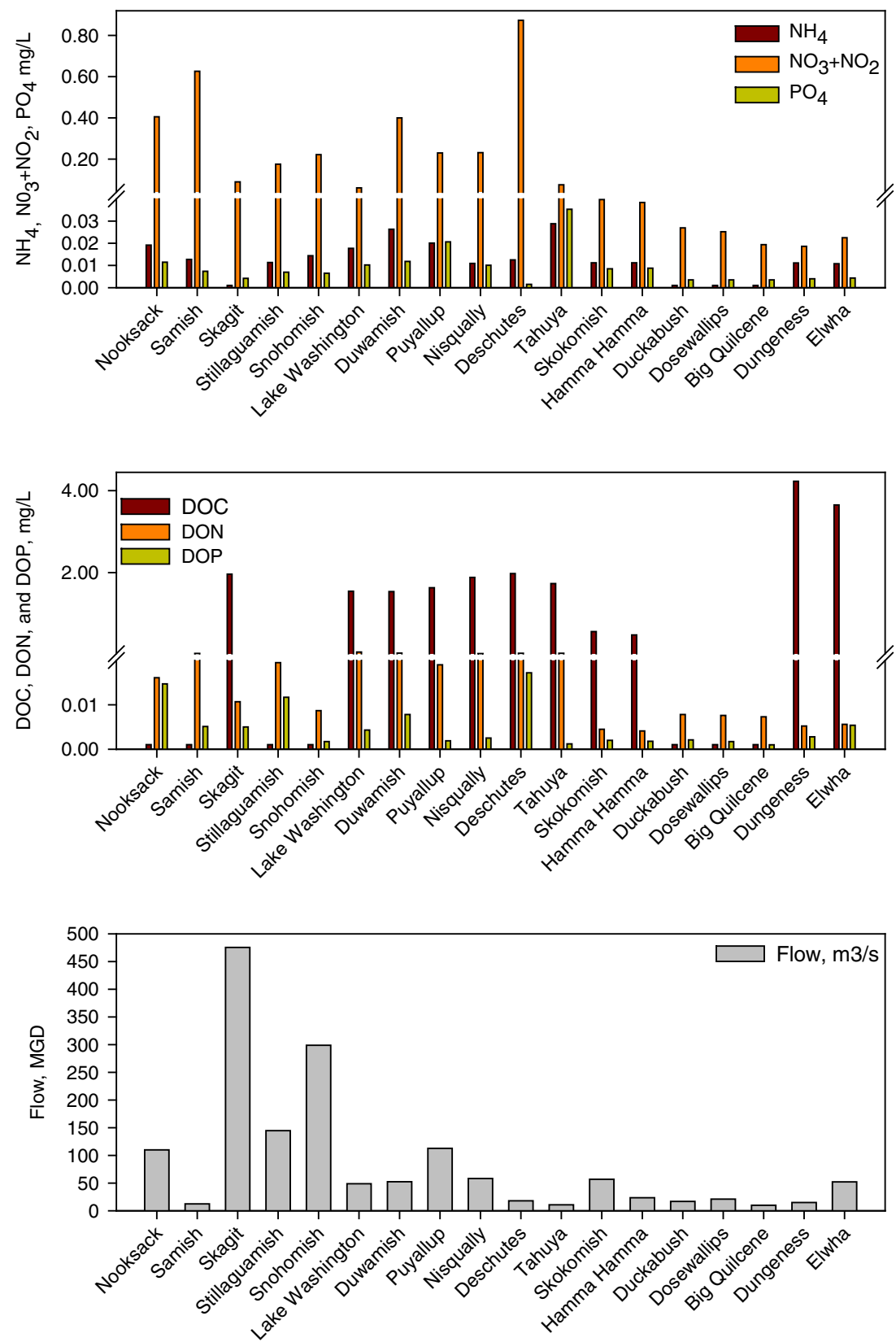

from point sources is tracked directly in the form of dissolved or particulate organic carbon, organic nitrogen, and organic phosphorous. This differs from the approach of tracking dissolved organic matter (DOM) and detritus separately prior to breakdown into nutrients and carbon as conducted on other water-quality models such as CE-QUAL-W2 (Cole and Buchak 1995). In its current configuration, no distinction is made in the properties of organic matter entering the model domain from different sources. Fluxes of organic carbon, nitrogen, and phosphorous (subdivided into labile/refractory and particulate/ dissolved forms) are specified at individual point source locations.
The CE-QUAL-ICM model solves the 3-D massconservation equation for a control volume, making it amenable for use with unstructured-grids. The governing equation (Cerco and Cole 1994) is as follows:

$\frac{\partial V_{j} C_{j}}{\partial t}=\sum_{k=1}^{n} Q_{k} C_{k}+\sum_{k=1}^{n} A_{k} D_{k} \frac{\partial C}{\partial x_{k}}+\sum S_{j}$

where $V_{j}$ is volume of the $j$ th control volume (cubic meter), $C_{j}$ is the concentration in the $j$ th control volume (milligrams per liter), $Q_{k}$ is the flow across the flow face $\mathrm{k}$ of the 
Fig. 5 (continued)
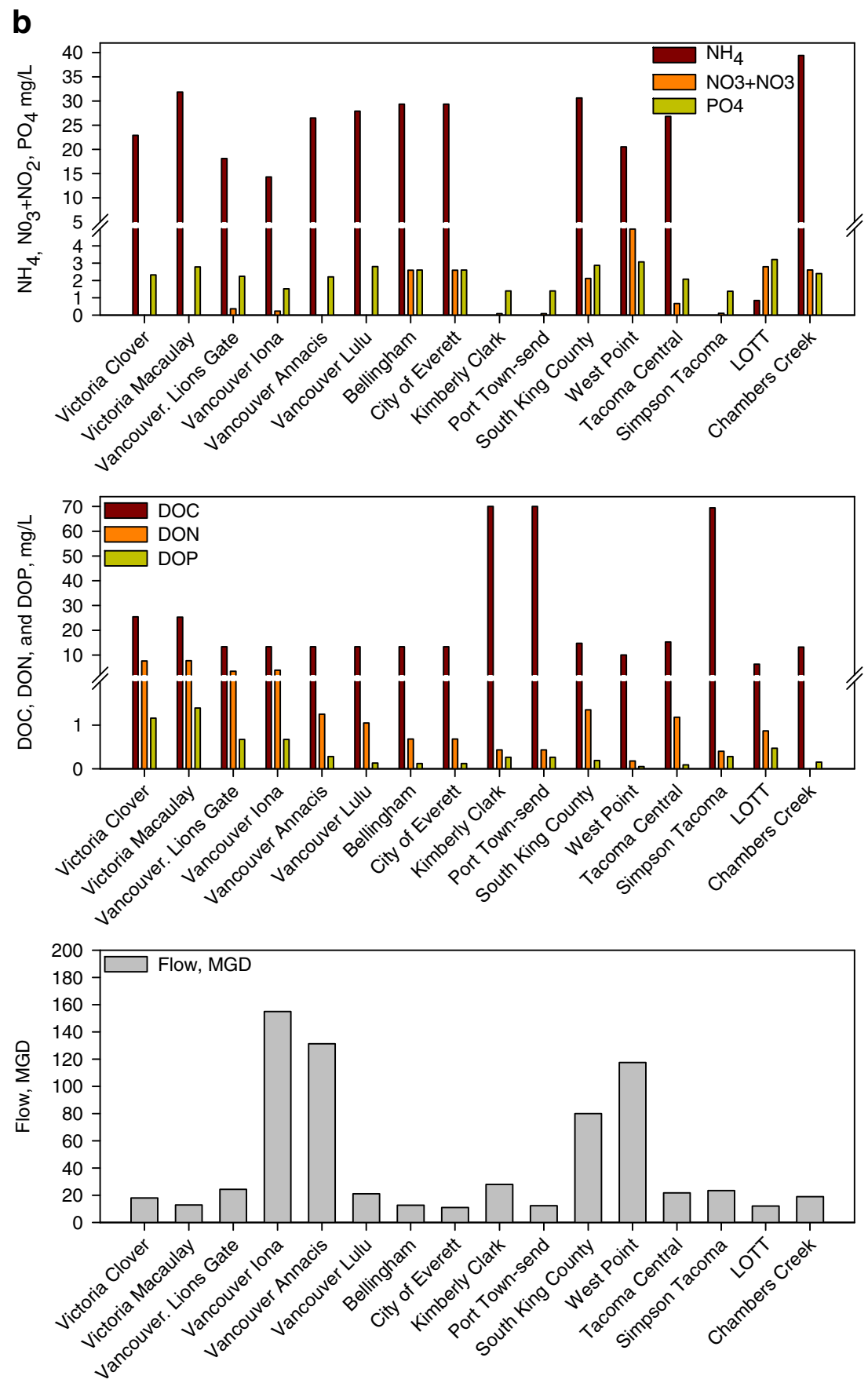

$j$ th control volume (cubic meter per second), $C_{k}$ is the concentration in the flow across the flow face $k$ (milligrams per liter), $A_{k}$ is the area of the flow face $k$ (square meter), $D_{k}$ is the diffusion coefficient at the flow face $\mathrm{k}$ (square meter per second), $n$ is the number of flow faces attached to the $j$ th control volume, $S$ represents the external loads and kinetic sources/sinks in the $j$ th control volume (grams per second), $t$ is the temporal coordinate, and $x$ is the spatial coordinate. The formulations for kinetics of sources and sinks for the biogeochemical state variables are identical to those found in Cerco and Cole (1995) and are not repeated here.
Linkage of FVCOM hydrodynamic solution with CEQUAL-ICM was accomplished through the development of a modified code herein referred to as the Unstructured Biological Model (UBM) in which the transport calculations are conducted through the FVCOM framework and biogeochemical calculations are conducted using CE-QUAL-ICM kinetics over the same finite volume mesh, as used in hydrodynamic calculations using a triangular elements. The scalar quantities, such as water surface elevation, temperature, salinity, and the water-quality state variable concentrations, are computed at the cell nodes, and vector 
quantities, such as lateral velocities, are computed at the cell centroid. The water-quality transport equation of UBM with $\sigma$-stretched coordinate system is as follows:

$$
\begin{gathered}
\frac{\partial \theta D}{\partial t}+\frac{\partial \theta u D}{\partial x}+\frac{\partial \theta v D}{\partial y}+\frac{\partial \theta \omega}{\partial \sigma}=\frac{\partial}{\partial x}\left(A_{h} H \frac{\partial \theta}{\partial x}\right)+ \\
\frac{\partial}{\partial y}\left(A_{h} H \frac{\partial \theta}{\partial y}\right)+\frac{1}{D} \frac{\partial}{\partial \sigma}\left(A_{v} \frac{\partial \theta}{\partial \sigma}\right)+D S
\end{gathered}
$$

where $\theta$ is water quality state variable, $D$ is total depth $(H+\zeta)$, where $H$ is the mean water depth and $\zeta$ is the water surface elevation, and $u, v, \omega$ are $x, y, \sigma$ velocity components, respectively. $A_{\mathrm{h}}$ is the horizontal diffusivity, $A_{\mathrm{v}}$ is the vertical diffusivity, and $S$ is the biogeochmemical sink/source term calculated using CE-QUAL-ICM kinetics.

When UBM is executed, it reads in all of the FVCOM information and uses it to conduct transport and biogeochemical calculations. First, the FVCOM mesh information is read into the UBM, followed by the hydrodynamic information, including velocity, diffusivities, open boundary fluxes, and water levels. Scalars computed in the hydrodynamic step required for the biogeochemical computations, including salinity, and temperature, are also read into the UBM. The UBM then reads in the initial conditions for the model domain and the external loads from the open boundaries, river boundaries, and point and non-point sources of nutrients. This information includes loadings for each of the 19 biogeochemical model state variables as either masses or fluxes. Once these data are read in to the model, biogeochemical calculations are conducted. A schematic flow diagram of the linked model UBM is provided in Fig. 6. The technical details describing the development of the offline coupling of FVCOM and CE-QUAL-ICM are provided in detail by Kim and Khangaonkar (2011).

\section{Salish Sea model setup and calibration}

\subsection{Initial conditions}

Year 2006 was identified as the most recent data-rich period for salinity, temperature, and water quality (nutrients, phytoplankton, and DO) and selected for the model calibration effort. In general, 2006 late-summer oxygen levels represented somewhat average conditions over the past 10 years (Krembs 2011). Examination of data from winters of 2005 and 2006 showed that the water column was relatively homogeneous and fully mixed. At first, data from the Puget Sound Main Basin station PSB003 from 2005 were used to initialize the model throughout the domain. Nutrients (inorganic $\mathrm{N}$ and $\mathrm{P}$ ), chlorophyll $a$ (converted to carbon using a carbon to chlorophyll $a$ ratio of 50), and DO specified as initial conditions are listed in Table 2. Due to limited availability of data, the remaining constituents were set to zero. For simplicity, uniform initial conditions were chosen. This approach assumes that during the winter, biological activity is low and, by the time spring bloom occurs, the remaining constituents will be internally updated, filled via boundary fluxes and transformation from the other pools. Results at the end of 1 year were treated as preconditioning spin-up and were then used to re-initialize the model. The simulation for year 2006 was then repeated.

\subsection{Benthic fluxes}

Within Puget Sound there are many depositional areas with limited flushing where uptake due to sediment oxygen demand is expected to be significant and limited measurements have been conducted in the past (e.g., Pamatmat 1971; Brandes and Devol 1995). Brandes and Devol
Fig. 6 Schematic flow diagram of linkage between FVCOM and CE-QUAL-ICM

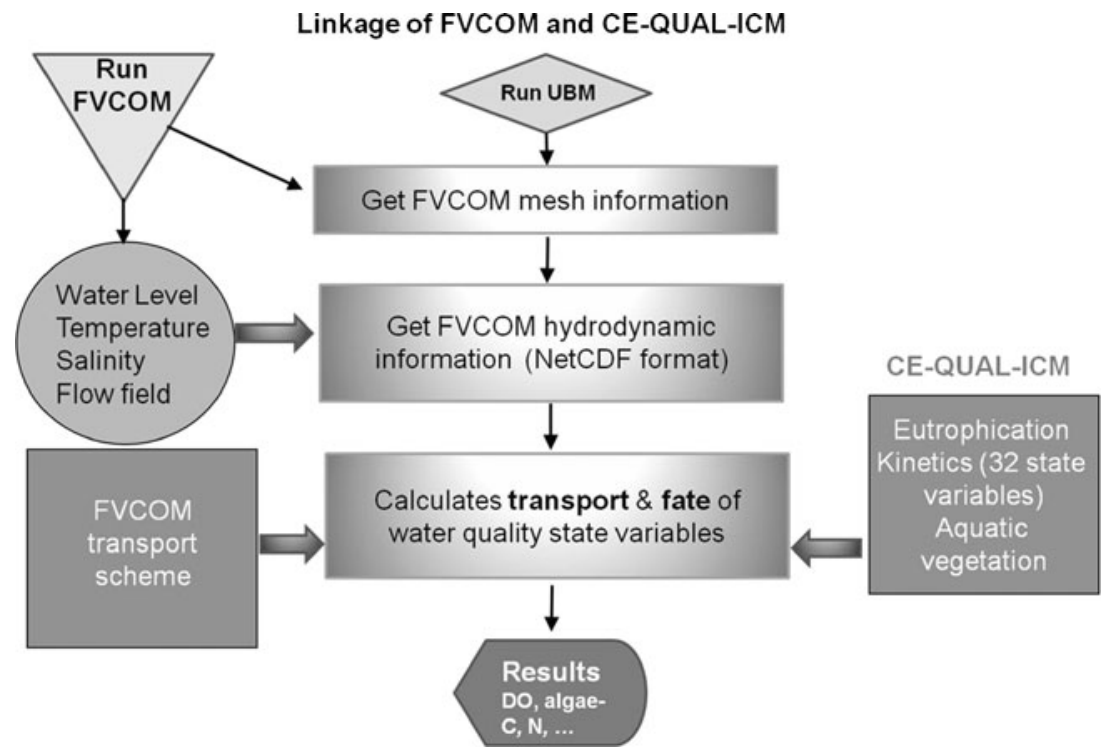


Table 2 Initial water quality concentrations for the 2006 simulation from Puget Sound Main Basin Station PSB003 and Hood Canal Station HCB003 (December 7, 2005) used in the pre-conditioning spin-up simulation

\begin{tabular}{|c|c|c|c|c|c|}
\hline Basin & $\mathrm{DO}, \mathrm{mg} / \mathrm{L}$ & $\mathrm{NO}_{3}+\mathrm{NO}_{2}, \mathrm{mg} / \mathrm{L}$ & $\mathrm{NH}_{4}, \mathrm{mg} / \mathrm{L}$ & $\mathrm{PO}_{4}, \mathrm{mg} / \mathrm{L}$ & Algae, mg/L \\
\hline Puget Sound Domain (except Hood Canal) & 8.0 & 0.43 & 0.002 & 0.08 & 0.026 \\
\hline Hood Canal & $\begin{array}{l}\text { Surface (9.0) } \\
\text { Bottom (4.0) }\end{array}$ & 0.43 & 0.002 & 0.08 & 0.026 \\
\hline
\end{tabular}

(1995) concluded that relatively few short-lived reaction sites could be responsible for most oxygen and nitrogen reductions in sediments in shallow seas. Grundamnis and Murray (1977) pointed out that denitrification in low DO regions of Puget Sound could cause an even greater sink of nitrogen than previously thought to be caused by burrowing of benthic organisms. Benthic sediment fluxes were therefore specified for DO, ammonium, nitrate and nitrite, and phosphate based on recent field measurements (Roberts et al. 2008). These data shown in Table 3 are conservative (higher fluxes than would be expected on average in the Salish Sea) because they include data collected during the summer in a very shallow region of Puget Sound, the Budd Inlet. Constant fluxes were used for nitrate + nitrite, ammonia, and phosphate. However for DO, a spatially varying benthic flux with high demand of $2.0 \mathrm{gm}^{-2}$ day $^{-1}$ was specified in selected shallow areas of Puget Sound with known occurrences of low DO conditions. A value of $0.1 \mathrm{gm}^{-2}$ day ${ }^{-1}$ was specified for the rest of Puget Sound domain.

\subsection{Boundary conditions}

Since the 1950s, researchers have pointed out the importance of the process by which water trapped behind the sills in fjords such as Puget Sound is replaced by water of greater density that flows in over the sills (e.g., Barnes and Collias 1958; Geyer and Cannon 1982). This inflow in the summer months is fed by coastal upwelling which supplies most of the macronutrients available for production (Mackas and Harrison 1997; Hickey and Banas 2003). Nutrient, phytoplankton, algal biomass, and DO monitoring data collected at the open boundaries by DFO, the Washington State Department of Ecology, and UW as part of the Joint Effort to Monitor the
Strait of Juan de Fuca (JEMS) program from year 2006 were considered for specification of appropriate boundary values for this calibration. Figure $7 \mathrm{a}, \mathrm{b}$ show quarterly profiles collected by DFO from sites nearest to the boundaries. These data were supplemented by the monthly profiles from JEMS data sets from the Strait of Juan de Fuca inner basin, resulting in a composite boundary concentrations file for 2006. Strait of Juan de Fuca boundary nitrate + nitrite concentrations are approximately $0.4 \mathrm{mg} / \mathrm{L}$ at depth throughout the year, with concentrations approximately half of this value $(0.1-0.2 \mathrm{mg} / \mathrm{L})$ at the surface during the summer. Inorganic phosphate follows a similar pattern but at an order of magnitude lower concentrations. In the Georgia Strait, the nutrient concentrations are similar at depth, but reach zero for nitrate and near zero for phosphate in the surface during the summer months. This strongly suggests effects of local primary productivity and consumption of nutrients from the surface layers during the summer. DO is relatively high in the surface layer $(\sim 7 \mathrm{mg} / \mathrm{L})$ during the spring and winter months (reflecting algal growth in the spring and mixing and reaeration in the winter months). In late summer and autumn, DO decreases slightly in the surface layer to $6-7 \mathrm{mg} / \mathrm{L}$, with concentrations decreasing much more quickly with depth than at other times of year, such that concentrations reach $\sim 4 \mathrm{mg} / \mathrm{L}$ at $50 \mathrm{~m}$ in autumn (this concentration occurs around $100 \mathrm{~m}$ during the rest of the year). DO is quite low at depth, $2-4 \mathrm{mg} / \mathrm{L}$ throughout the year in waters deeper than $100 \mathrm{~m}$.

\subsection{Calibration and parameterization through sensitivity} tests

Initial model setup was conducted using literature values for the model parameters. Many model runs were then

Table 3 Benthic sediment fluxes (5-cm depth) — nutrients and dissolved oxygen specified throughout the Puget Sound model domain

\begin{tabular}{lllll}
\hline Constituent & $\mathrm{NO}_{3}+\mathrm{NO}_{2}$ & $\mathrm{NH}_{4}$ & $\mathrm{PO}_{4}$ & $\mathrm{DO}$ \\
\hline Specified benthic flux $\left(\mathrm{g} \mathrm{m}^{-2} \mathrm{day}^{-1}\right)$ & -0.011 & 0.064 & 0.02 & $-0.1^{\mathrm{a}}$ \\
Measured data range $\left(\mathrm{g} \mathrm{m}^{-2} \mathrm{day}^{-1}\right)$ & -0.004 to -0.016 & 0.03 to 0.12 & 0.0 to 0.05 & -0.24 to -1.71 \\
\hline
\end{tabular}

${ }^{a}$ Value specified in most of Salish Sea domain

${ }^{\mathrm{b}}$ Value specified in selected shallow regions of Puget Sound known for low values of near bed DO 
Fig. 7 a Nitrate + nitrite and phosphate profiles at Georgia Strait and Strait of Juan de Fuca boundaries (Source: Department of Fisheries and Oceans Canada). b Dissolved oxygen and algal carbon at Georgia Strait and Juan de Fuca boundaries (Source: Department of Fisheries and Oceans Canada) a
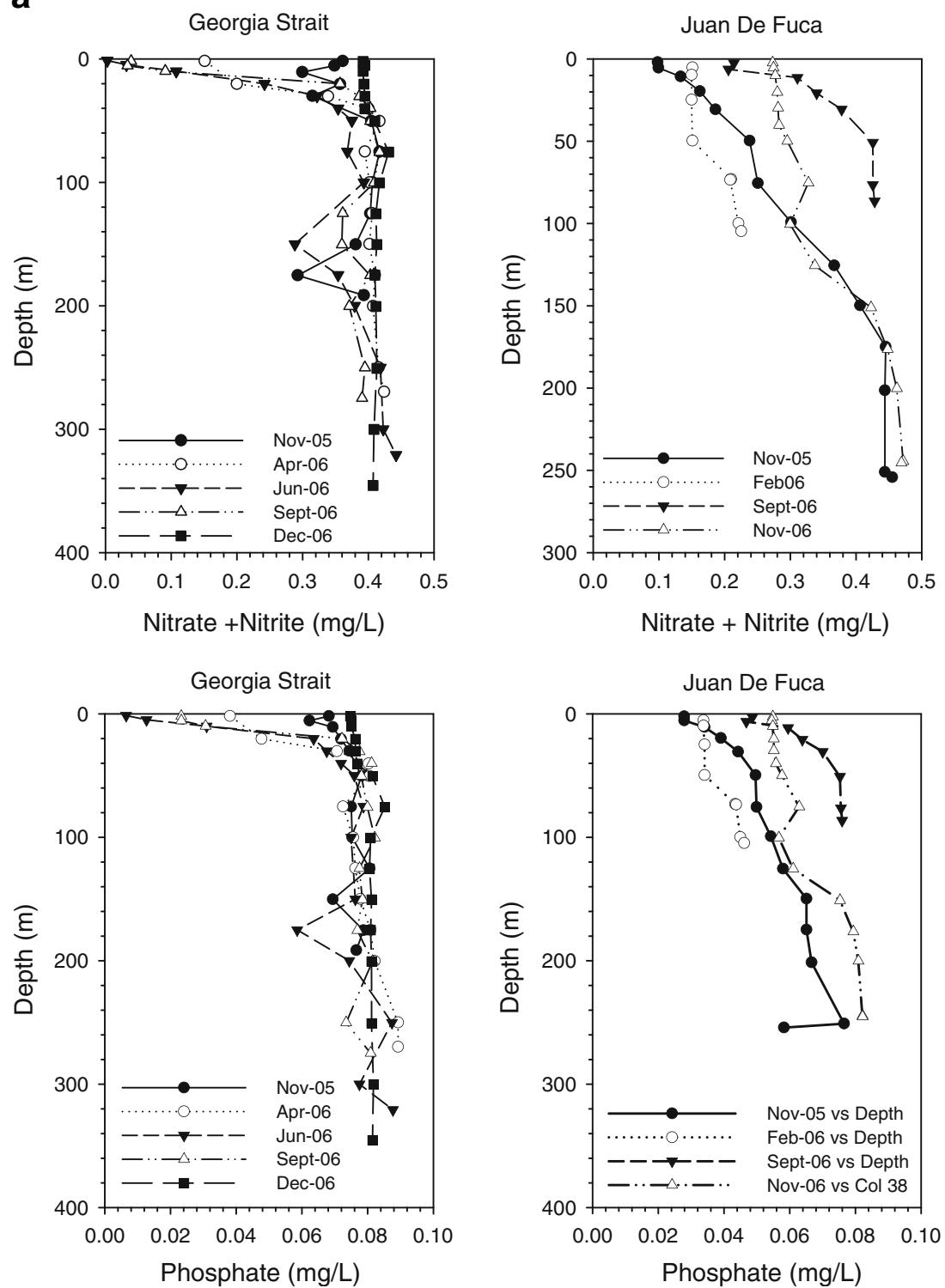

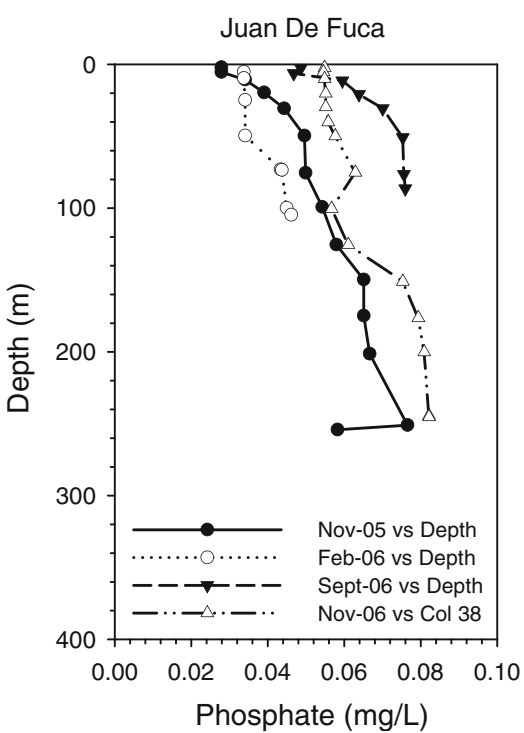

conducted to identify the parameters that affected predicted nutrients, algal biomass (chlorophyll $a$ ), and DO concentrations most strongly. The parameters were then adjusted using best professional judgment until predicted results best reproduced observed DO, nutrients, and chlorophyll $a$ data. The model results were most sensitive to maximum photosynthetic rate for algae $\left(P_{\max }\right)$, carbon to chlorophyll ratios, grazing loss rate, reaeration parameterizations, and settling rates, and half saturation constants of nutrient uptake. In this calibration effort, algal nutrient ratios have been kept static at the Redfield ratios $(106: 16: 1$ for $\mathrm{C} / \mathrm{N} / \mathrm{P})$. The calibration is limited to some degree by a paucity of primary production and other rate and kinetic data for Puget Sound. Of the few data reported, ranges for primary production vary from the 265 and $465 \mathrm{gC} \mathrm{m}^{-2}$ year $^{-1}$ reported by Winter et al. (1975) to 694 to $1,241 \mathrm{gC} \mathrm{m}^{-2}$ year $^{-1}$ reported by Ruef et al. (2003). Puget Sound rates normalized to chlorophyll $a$ were reported by Winter et al. (1975) to range from 96 to $120 \mathrm{mg} \mathrm{C} \mathrm{mg} \mathrm{Chl}{ }^{-1}$ day $^{-1}$. Efforts have been made to quantify the phytoplankton contributors to the carbon pool, with diatom bloom during the late winter to early spring period and summer bloom by other species (Connell and Jacobs 1998; Horner et al. 2005; Rensel 2007). Integrated chlorophyll $a$ over the water column has ranged over the past 40 years of sampling between 10 and $400 \mathrm{mg} \mathrm{Chl} \mathrm{m}{ }^{-2}$; typically, spring integrated chlorophyll $a$ is $\sim 250 \mathrm{mg} \mathrm{m}^{-2}$ (Horner et al. 2005). Grazing rates for copepods typically range from 0.2 to 0.4 day (e.g., McAllister 1970).

For nutrient uptake, general ranges surrounding the estuarine half-saturation constants were tested during the 
Fig. 7 (continued)

b
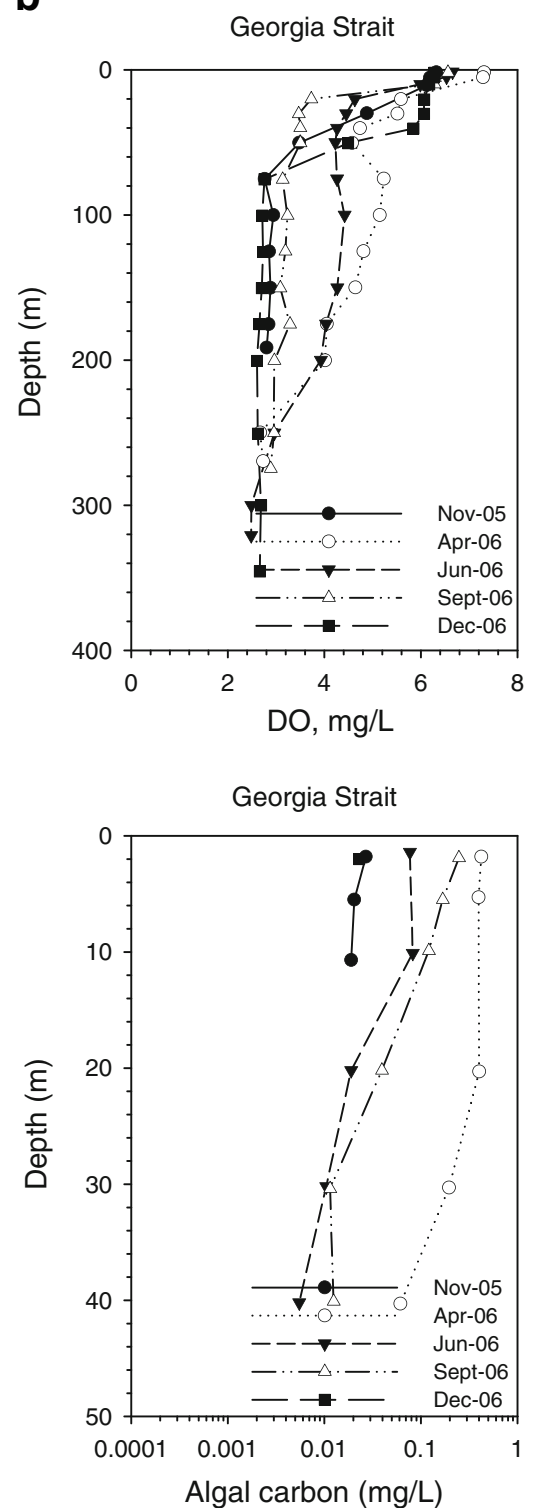
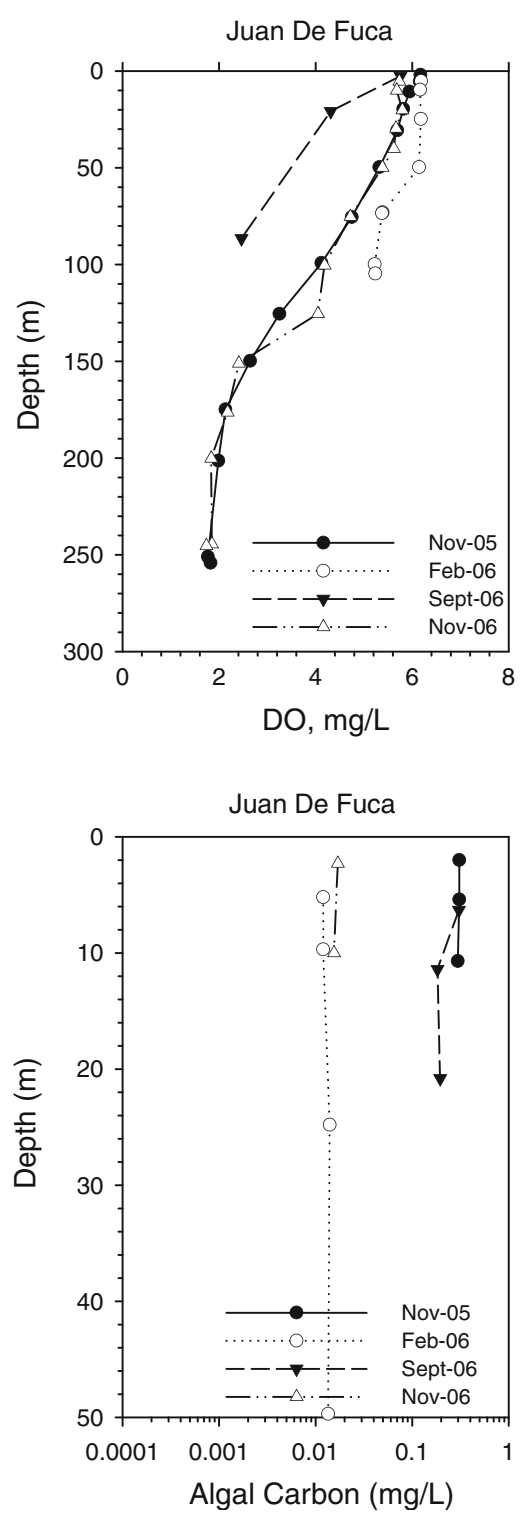

calibration, with the best fit at the upper end of the half-saturation constant range for $\mathrm{N}$ and $\mathrm{P}$. The halfsaturation constants based on data from 17 species of marine phytoplankton have been reported in the range from 0.001 to $0.144 \mathrm{mg} \mathrm{N} / \mathrm{L}$ (Eppley et al. 1969; Herndon and Cochlan 2007). However, there are numerous additional phytoplankton species in Puget Sound, such that half-saturation constants for nitrogen can be much higher, with maxima of $4.34 \mathrm{mg} \mathrm{N} / \mathrm{L}$ (Bowie et al. 1985). Phosphorus half-saturation constants for dinoflagellates range from 0.0003 to $0.195 \mathrm{mg} \mathrm{P} / \mathrm{L}$ and for diatoms range from 0.001 to $0.163 \mathrm{mg} \mathrm{P} / \mathrm{L}$ (Bowie et al. 1985).

The parameters known to influence algal growth and oxygen depletion in the water column may actually vary considerably in different parts of Puget Sound.
Typical ranges of carbon-to-chlorophyll a ratio $(\mathrm{C} / \mathrm{Chl})$ recorded in Dabob Bay, Puget Sound, were 25-65 (Horner et al. 2005). In this model, we simulate static $\mathrm{C} / \mathrm{Chl}$ with a base ratio of 37 for diatoms and 50 for dinoflagellates. One of the key parameters of algal growth is the optimum temperature at which algal growth rate is highest assuming appropriate light and nutrients are available. The values of optimum temperatures may vary depending on the location based on sitespecific conditions and acclimatization. For example, optimum temperature may range from 20 to $35{ }^{\circ} \mathrm{C}$ in tropical waters (Bowie et al. 1985). But optimum temperatures may be much lower in higher latitudes where waters are naturally cooler. For example, the water temperature in Puget Sound is usually less than $20{ }^{\circ} \mathrm{C}$ and some of the phytoplankton species (like Heterosigma 
carterae) proliferate when the water temperature becomes 16 to $18{ }^{\circ} \mathrm{C}$. Similarly, the spring bloom of diatoms is known to occur during the March-April period when water temperatures are $10-12{ }^{\circ} \mathrm{C}$. The optimum temperature parameter was used during the calibration to adjust the timing of the spring and summer algae bloom onset and separation of peaks. Zooplanktons were not simulated explicitly, but the effect was incorporated through algal base predation rate, specified relatively high. Table 4 lists all model parameters used in the calibration along with ranges of values found in the literature (Bowie et al. 1985; Cerco and Cole 1994; Bunch et al. 2000; Cerco et al. 2000; Tillman et al. 2004). Bienfang and Harrison (1984) noted in their study that the settling rates of large centric diatoms were higher than dinoflagellates $(0.96$ and $0.22 \mathrm{~m}^{-1}$, respectively). Settling rates specified for diatoms and dinoflagellates were 0.4 and $0.2 \mathrm{~m} \mathrm{day}^{-1}$, respectively. The model uses a time step of $20 \mathrm{~s}$, operates over exactly the same grid (9,013 nodes and 13,941 elements) as the hydrodynamic model, and generates a 1 -year solution in $\approx$ $24 \mathrm{~h}$ on a 35 -processor cluster computer.

\section{Results and discussion}

We have adopted a phased approach towards the development of Salish Sea model such that in this first phase we focused on obtaining a reasonable reproduction of the biological behavior over the larger domain with the expectation

Table 4 List of key model parameters

\begin{tabular}{|c|c|c|c|c|}
\hline Symbol & Value & Unit & Literature range & Definition \\
\hline $\mathrm{P}_{\mathrm{m} \_ \text {dia }}$ & $200-350^{\mathrm{a}}$ & $\mathrm{g} \mathrm{Cg}^{-1} \mathrm{Chl} \mathrm{day}{ }^{-1}$ & $200-350$ & Maximum photosynthetic rate of diatoms \\
\hline $\mathrm{P}_{\mathrm{m} \_ \text {dino }}$ & $250-350^{\mathrm{a}}$ & $\mathrm{g} \mathrm{C} \mathrm{g}^{-1} \mathrm{Chl}$ day $^{-1}$ & $200-350$ & Maximum photosynthetic rate of dinoflagellates \\
\hline $\mathrm{T}_{\text {opt_dia }}$ & 12 & ${ }^{\circ} \mathrm{C}$ & up to 35 & Optimal temperature for growth of diatoms \\
\hline $\mathrm{T}_{\text {opt_dino }}$ & 18 & ${ }^{\circ} \mathrm{C}$ & up to 35 & Optimal temperature for growth of dinoflagellates \\
\hline $\mathrm{BM}_{\mathrm{dia}}$ & 0.1 & day $^{-1}$ & $0.01-0.1$ & Basal metabolic rate of diatoms \\
\hline $\mathrm{BM}_{\text {dino }}$ & 0.1 & day $^{-1}$ & $0.01-0.1$ & Basal metabolic rate of dinoflagellates \\
\hline $\mathrm{W}_{\mathrm{a} \_ \text {dia }}$ & 0.4 & $\mathrm{~m} \mathrm{day}^{-1}$ & $0-30$ & Settling velocity of diatoms \\
\hline $\mathrm{W}_{\mathrm{a} \_ \text {dino }}$ & 0.2 & $\mathrm{~m}_{\text {day }}{ }^{-1}$ & $0-30$ & Settling velocity of dinoflagellates \\
\hline $\mathrm{BPR}_{\mathrm{dia}}$ & 1.0 & day $^{-1}$ & $0.05-1.0$ & Base predation rate of diatoms \\
\hline $\mathrm{BPR}_{\text {dino }}$ & 0.5 & day $^{-1}$ & $0.05-1.0$ & Base predation rate of dinoflagellates \\
\hline CChl & 37 & $\mathrm{~g} \mathrm{C} \mathrm{g}^{-1} \mathrm{Chl}$ & $30-143$ & Carbon-to-chlorophyll ratio diatoms \\
\hline CChl & 50 & $\mathrm{~g} \mathrm{C} \mathrm{g}^{-1} \mathrm{Chl}$ & $30-143$ & Carbon-to-chlorophyll ratio dinoflagellates \\
\hline $\mathrm{NT}_{\mathrm{m}}$ & 0.4 & $\mathrm{~g} \mathrm{~N} \mathrm{~m}^{-3}$ day $^{-1}$ & $0.01-0.7$ & Maximum nitrification rate \\
\hline $\mathrm{T}_{\mathrm{mnt}}$ & 30 & ${ }^{\circ} \mathrm{C}$ & $25-35$ & Optimal temperature for nitrification \\
\hline Kldc & 0.025 & day $^{-1}$ & $0.005-0.25$ & Minimum respiration rate of $\mathrm{LDOC}$ \\
\hline Krdc & 0.0015 & day $^{-1}$ & - & Minimum respiration rate of $\mathrm{RDOC}$ \\
\hline Klpc & 0.05 & day $^{-1}$ & $0.005-1.5$ & Dissolution rate of LPOC \\
\hline Krpc & 0.0015 & day $^{-1}$ & $0.001-0.005$ & Dissolution rate of RPOC \\
\hline $\mathrm{KH}_{\text {odoc }}$ & 0.5 & $\mathrm{~g} \mathrm{O}_{2} \mathrm{~m}^{-3}$ & 0.5 & Half-saturation concentration of dissolved oxygen \\
\hline KHn_dia & 0.06 & $\mathrm{~g} \mathrm{~N} \mathrm{~m}^{-3}$ & $0.003-0.923$ & Half-saturation concentration for nitrogen uptake by diatoms \\
\hline $\mathrm{KHn}_{\text {dino }}$ & 0.06 & $\mathrm{~g} \mathrm{~N} \mathrm{~m}^{-3}$ & $0.005-0.589$ & Half-saturation concentration for nitrogen uptake by dinoflagellates \\
\hline KHp_dia & 0.02 & $\mathrm{~g} \mathrm{P} \mathrm{m}^{-3}$ & $0.001-0.163$ & Half-saturation concentration for phosphorus uptake by diatoms \\
\hline $\mathrm{KHp}_{\text {dino }}$ & 0.02 & $\mathrm{~g} \mathrm{P} \mathrm{m}^{-3}$ & $0.0003-0.195$ & $\begin{array}{l}\text { Half-saturation concentration for phosphorus uptake by } \\
\text { dinoflagellates }\end{array}$ \\
\hline $\mathrm{K}_{\mathrm{r}}$ & Calculated & & - & Reaeration coefficient \\
\hline $\begin{array}{l}\mathrm{FT}_{\mathrm{SOD}} \\
\text { Presp_dia }\end{array}$ & $0.1-2.0^{\mathrm{b}}$ & $\mathrm{g} \mathrm{m}^{-2}$ day $^{-1}$ & - & SOD coefficient \\
\hline \multirow[t]{2}{*}{ Presp_dino } & 0.25 & $0 \leq$ Presp $\leq 1$ & $0-1$ & Photo-respiration fraction of diatoms \\
\hline & 0.25 & $0 \leq$ Presp $\leq 1$ & $0-1$ & Photo-respiration fraction of dinoflagellates \\
\hline $\mathrm{W}_{1}$ & 0.25 & $\mathrm{~m} \mathrm{day}^{-1}$ & $0.03-0.8$ & Settling velocity of labile particles \\
\hline $\mathrm{W}_{\mathrm{r}}$ & 0.25 & $m$ day $^{-1}$ & $0.03-0.8$ & Settling velocity of refractory particles \\
\hline
\end{tabular}

LDOC labile dissolved organic carbom, RDOC refractory dissolved organic carbon, $S O D$ sediment oxygen demand

${ }^{\text {a }}$ Value specified in subbasins - Hood Canal, Whidbey Basin, Bellingham Bay, and South Puget Sound

${ }^{\mathrm{b}}$ Value specified in selected shallow regions of Puget Sound known for low values of near bed DO 
that site-specific refinements and calibration will continue to improve the model performance in the inner reaches in subsequent phases. Through comparisons of simulated results and measured data for algal biomass, nitrates, and DO, we have developed an understanding of the annual biogechemical cycles observed in the Salish Sea including Puget Sound. The data and model results show that bulk of the tidally averaged residual exchange flow which enters Salish Sea is from the Strait of Juan de Fuca boundary at depth. A portion of this inflow ( $\approx 13 \%$ in 2006) enters Puget Sound over the Admiralty Inlet sill while the remaining flow traverses around San Juan Islands to Georgia Strait and the Canadian waters. The inflow at depth brings nutrient-rich waters to the Salish Sea. The inflow undergoes mixing with the surface outflow in the Strait of Juan de Fuca and further mixing with brackish outflow over the Admiralty Inlet sill. The incoming higher salinity water then enters Hood Canal basin and the main basin of Puget Sound. Water entering the main basin of Puget Sound entrains some more surface fresh water through the reflux phenomenon at the Admiralty Inlet sill. Effects of these physical mixing processes are reflected in the bottom water nutrient and DO concentrations in model simulation results as well as measured data. Although there is a large oceanic supply of nutrients, the stratified two layer circulation results in a shallow biologically active surface layer 5-20 m deep. The nutrient concentrations in this surface layer are routinely depleted during the spring and summer algae bloom periods. The efflux of bottom water at the Tacoma Narrows sill at the southern end of Puget Sound, and the Georgia Strait terminus near the north boundary at Johnstone Straits replenish the surface layer with nutrients following the end of biological activity in winter months (November-February). The months from May through October correspond to coastal upwelling period during which the bottom waters in Salish Sea experience a steady reduction in DO concentrations. The DO levels along with nutrient concentration appear to reset with cooler temperature higher nutrient waters from the Pacific Ocean during the winter.

A comparison between measured and predicted chlorophyll $a$ concentration in Puget Sound is shown in Fig. 8. The surface concentrations are from analyses of samples collected at the 1-m depth from the photosynthetically active, surface outflow layer of Puget Sound and are plotted against simulated algal biomass from two species of algae - diatoms and dinoflagellates. The spring bloom in Puget Sound is simulated using the diatoms algal group that peaks during April and May. The summer bloom is simulated using the dinoflagellates algal group that peaks during July and August. Algal biomass is highest in the interior inlets and passages, including Budd Inlet, Sinclair Inlet, Hood Canal, and Saratoga Passage. The stations within the main basin and near the Strait of Juan de Fuca showed lower biomass levels. One possible explanation for this variation in algal biomass may be temperature variability among the basins with surface waters in the main deeper basins of Puget Sound being a little cooler than the shallow subbasins. The main basin of the domain is also less stratified than Hood Canal and Whidbey Basin and likely experiences more mixing due to wind and inflows from the subbasins. Capturing this variability required specification of higher values of maximum photosynthetic rates in Hood Canal, Whidbey Basin, Bellingham Bay, and South Sound of $350 \mathrm{gC} \mathrm{g}^{-1} \mathrm{Chl}$ day $^{-1}$ relative to $200 \mathrm{gC} \mathrm{g}^{-1} \mathrm{Chl} \mathrm{day}^{-1}$ specified in rest of the domain for diatoms and $250 \mathrm{gC} \mathrm{g}^{-1} \mathrm{Chl} \mathrm{day}^{-1}$ for dinoflagellates.

Measured data show that chlorophyll $a$ concentrations in Puget Sound generally vary between 0 and $20 \mu \mathrm{g} / \mathrm{L}$. Budd Inlet station however is an exception because chlorophyll $a$ data show that peak concentrations in this basin are over four times higher than other basins in Puget Sound. The current model predictions do not reflect this pattern. Capitol Lake/Deschutes River system at the head waters of Budd Inlet is known to reach eutrophic levels of algal production in the summer. Although freshwater algae from Capitol Lake in the discharge to Budd Inlet are not likely to survive in marine waters, there is a possibility that they may be influencing algal biomass measurements and the intense patchy blooms seen in Budd Inlet.

Phytoplankton succession is important in the Puget Sound. The year 2006 included a significant dinoflagellate bloom, which affected many of the subbasins of Puget Sound. We have focused the calibration on phytoplankton succession of 2006 in terms of the magnitude and timing of the blooms. A diatom bloom occurred in the early spring, followed by a dinoflagellate bloom from late spring throughout the summer. The magnitude and spatial extent of the summer bloom were larger than usual, and have been attributed to a combination of factors, including aboveaverage runoff in the spring; relatively clear, dry, hot weather with low wind stress; and well-stratified water column conditions throughout the Sound in summer. Key parameters limiting algal growth were optimum temperature, halfsaturation constants for nitrogen, and light availability. Increase in available light and use of optimum temperatures for growth $\left(12\right.$ to $\left.18{ }^{\circ} \mathrm{C}\right)$ provided the best match for the timing of spring bloom of diatoms and summer bloom of dinoflagellates. These parameters, in combination with nutrient limitation imposed through the half-saturation constant $0.06 \mathrm{~g} \mathrm{~N} \mathrm{~m}^{-3}$ for nitrogen, allowed a separation between spring and summer blooms and the die-off in late fall.

The cumulative effects of the spring and summer blooms from the various basins are seen in nutrient concentrations in the mixed outflow waters. Figure 9a shows that the nitrite + nitrate concentrations dip from about $20-30 \mu \mathrm{mol} / \mathrm{L}$ in the winter to below $10 \mu \mathrm{mol} / \mathrm{L}$ in the spring and summer 

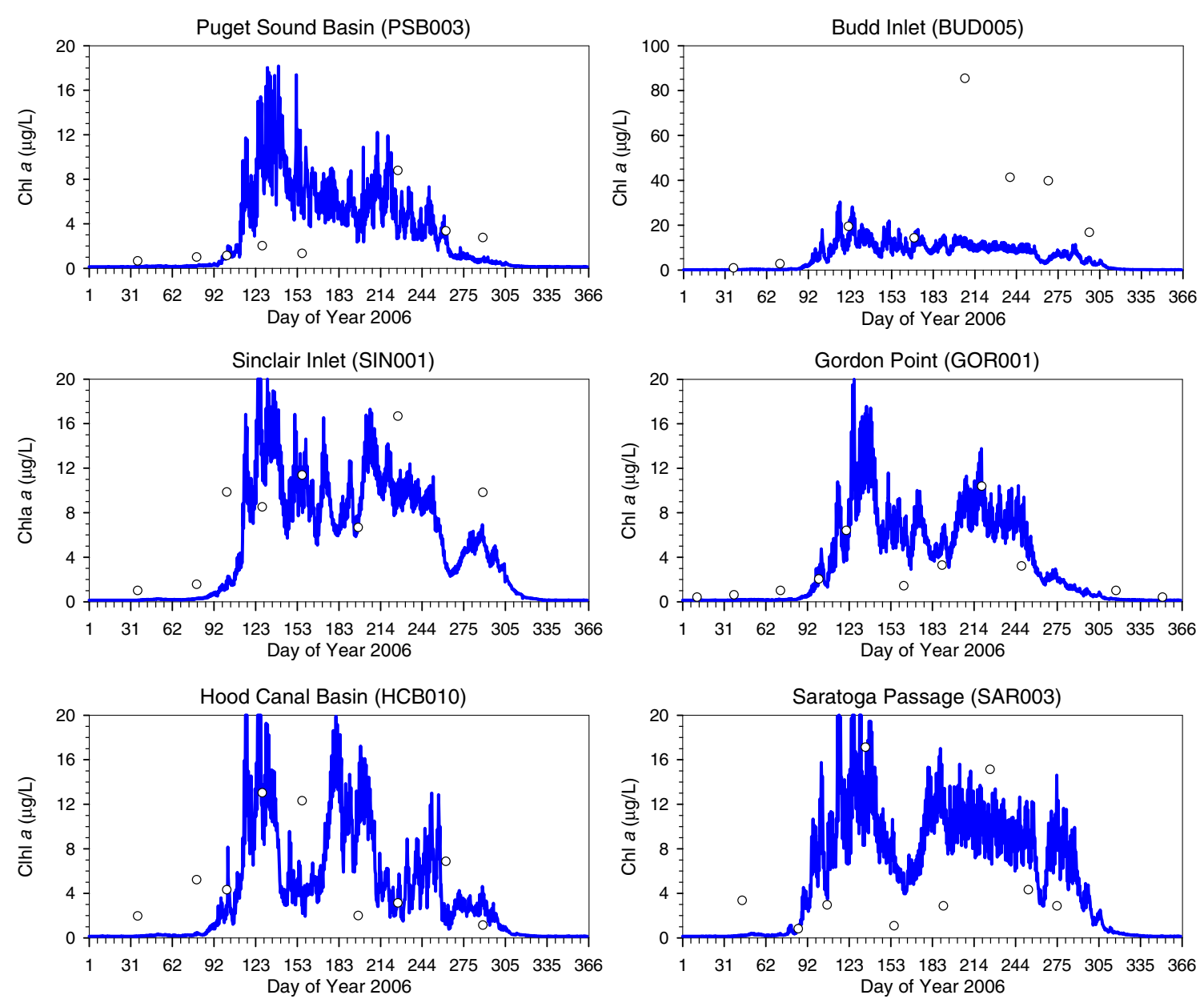

Fig. 8 Chorophyll $a$ time history — comparison of measured surface data at selected stations in Puget Sound with model results for year 2006

periods throughout Puget Sound. Due to higher levels of algal growth associated with spring and summer blooms, the surface concentrations of nitrate + nitrite in the shallow embayments, such as Sinclair Inlet and Budd Inlet, and fjordal subbasins such as Hood Canal and Saratoga Passage, were nearly depleted of nitrate and dropped to less than $2 \mu \mathrm{mol} / \mathrm{L}$. Bottom nutrient concentrations shown Fig. 9b reflect concentrations of water flowing into Puget Sound over the Admiralty sill at Puget Sound Basin, Hood Canal, and Gordon Point stations. These are deeper stations and concentrations at depth are not directly influenced by the productivity at the surface. However Budd Inlet and Sinclair Inlet being shallow stations show effects of strong mixing with surface waters. Figure 10a, b show phosphate concentration time histories in the surface and bottom layers, respectively. Despite being nearly an order of magnitude lower in concentrations $(0-3 \mu \mathrm{mol} / \mathrm{L})$, phosphate consumption associated with spring and summer blooms is also noticeable in the shallow embayments and the fjordal basins. The conceptual understanding of Puget Sound basin flushing and renewal is reconfirmed as nitrate + nitrite and phosphate concentrations bounce back from their depleted levels towards their original levels in the autumn months.

The concentrations of DO throughout the Sound were simulated, with deviations mostly due to offsets in the timing of phytoplankton blooms. The DO concentration in the surface layer around the Sound as shown in Fig. 11a was generally high, reflecting reaeration, phytoplankton primary production, and river input, especially during the winter months. In some locations that were quite productive, including Hood Canal year-round and Budd Inlet in summer, DO concentrations were near saturation or super-saturated at ambient temperatures, as would be expected with a strong phytoplankton bloom. As in the case of nutrients, during autumn months after the summer bloom period, the algal activity also reduces because of the reduced light availability

Fig. 9 a Nitrite + nitrate time history-comparison of measured surface data at selected stations in Puget Sound with model results for year 2006. b Nitrite + nitrate time history-comparison of measured bottom data at selected stations in Puget Sound with model results for year 2006, with the exception of Puget Sound Basin (PSB003) station plot where data was only available from the $30-\mathrm{m}$ depth 

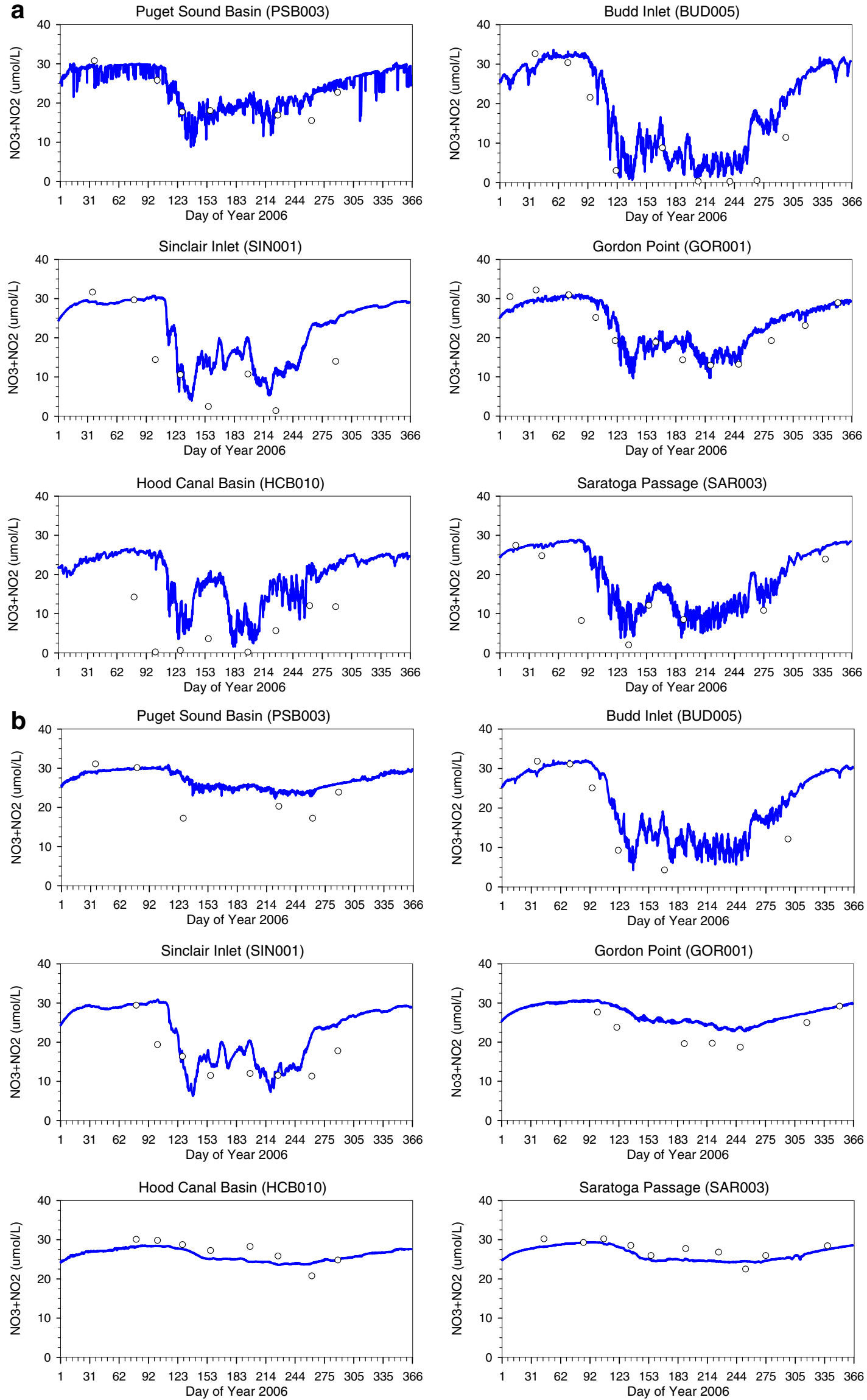

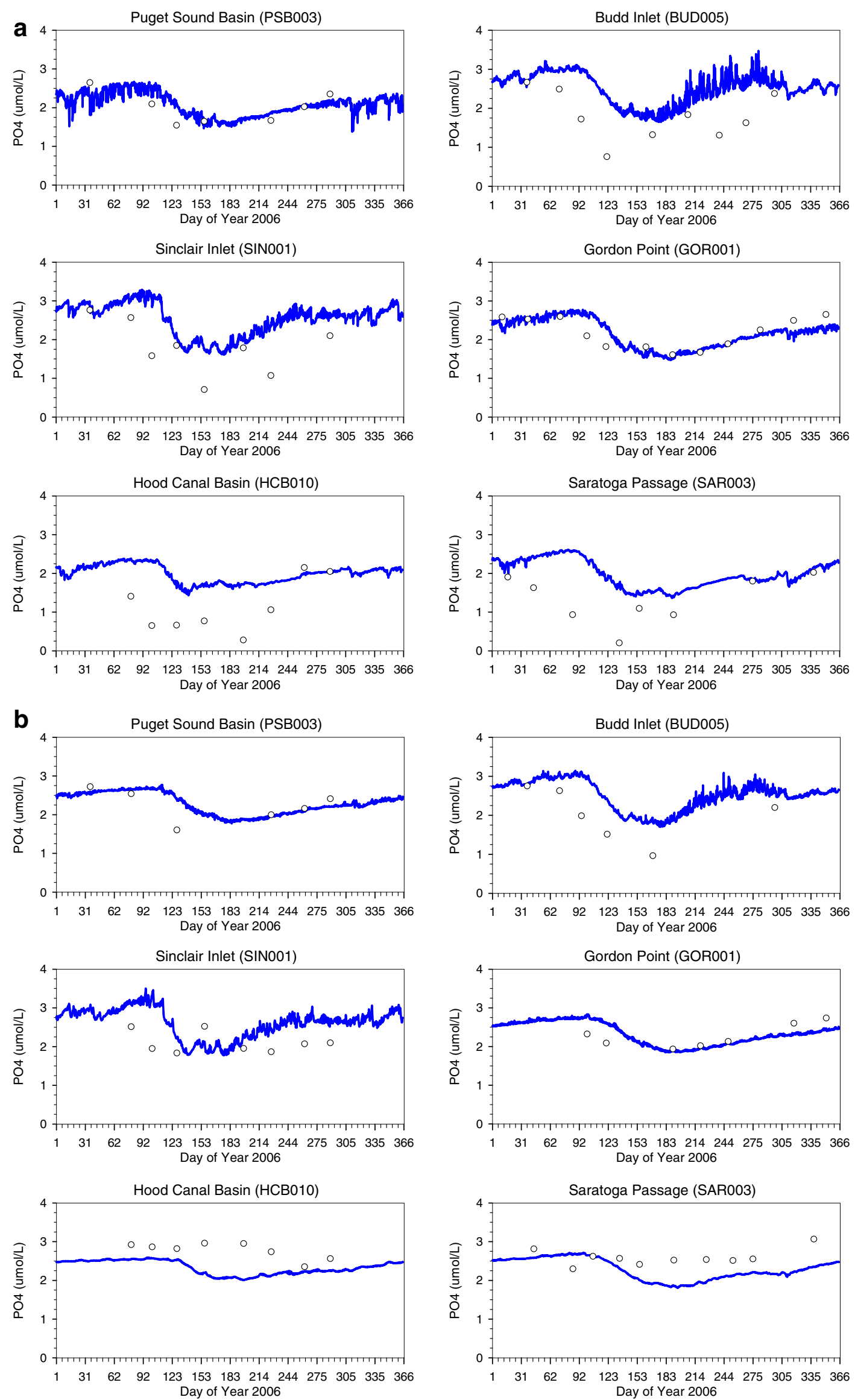
Fig. 10 a Phosphate time history-comparison of measured surface data at selected stations in Puget Sound with model results for year 2006. b Phosphate time history - comparison of measured bottom data at selected stations in Puget Sound with model results for year 2006, with the exception of Puget Sound Basin (PSB003) station plot where data was only available from the $30-\mathrm{m}$ depth

and lower temperatures, and DO concentrations in the surface layer return to their pre-bloom levels. Dissolved oxygen concentration at depth simulated in the model reflects a downward trend strongly influenced by the incoming low DO upwelled water from the Pacific Ocean via Admiralty Inlet (2-4 $\mathrm{mg} / \mathrm{L}$ during the summer) as shown in Fig. 11b. The near-bed DO concentrations in the fjordal subbasins show low DO concentrations that vary between 4 and $6 \mathrm{mg} / \mathrm{L}$. The nearbed DO levels are replenished as incoming DO levels rise during the post-upwelling autumn and winter months. In this phase, we have not attempted to match the hypoxic conditions $(\mathrm{DO}<2 \mathrm{mg} / \mathrm{L})$ observed in some of the inner reaches such as Lynch Cove in Hood Canal and South Puget Sound. While DO concentrations at a Puget Sound scale are dominated by the incoming waters from the Strait of Juan de Fuca, it is important to note that DO levels especially in the shallow nutrient limited subbasins, could be affected by smaller scale eutrophication processes and blooms perturbed by local anthropogenic discharges.

Error statistics for key biogeochemical variables - algal biomass (chlorophyll $a$ ), DO, nitrate + nitrite, and phosphate are provided in "Appendix" B. As discussed in Section "3.0", exceptionally high levels of algal biomass measured at the Budd Inlet station were not captured adequately in the model simulations and were not included in the error table. The error statistics indicate that predicted algal growth and DO concentration in the model are biased lower than the observed data. The root mean square (RMS) errors for DO vary between 1-2 mg/L. Simulated nitrate + nitrite levels are higher than observed, but consistent with the lower uptake associated with lower than observed simulated algae growth. The mean RMS error and bias for nitrate + nitrite are 4.78 and $2.38 \mu \mathrm{mol} / \mathrm{L}$, respectively, which are approximately 16 and $10 \%$ of the peak variation of nitrate + nitrite (0-30 $\mu \mathrm{mol} / \mathrm{L})$. Phosphate results show a good match with data with $<1 \mu \mathrm{mol} / \mathrm{L}$ of RMS error and bias at all stations.

\section{Conclusion}

In this paper, an offline intermediate-scale water-quality model for Puget Sound and the Northwest Straits (Salish Sea) using scalar transport scheme from the FVCOM model, coupled with the biogeochemical code of CE-QUAL-ICM was presented. A total of 19 state variables and key biogeochemical processes, including phytoplankton bloom dynamics, nutrient uptake, and re-mineralization, were simulated. The model includes nutrient loads from the ocean boundary, 19 major rivers, 64 nonpoint sources, and 99 point sources of wastewater discharge. Calibration of the model was conducted using observed waterquality data (chlorophyll $a$, nutrients, and DO) from the year 2006 using numerous sensitivity tests and best professional judgment to guide model parameter adjustment.

As a first effort to simulate biogeochemical balance over the entire Salish Sea domain using a numerical model, the performance in simulating observed behavior was encouraging. While the current model calibration is suitable for addressing the broad water quality management question of whether human sources of nutrients in and around Puget Sound are significantly affecting water quality and, if so, how much nutrient reduction is necessary to reduce human impacts in sensitive areas, targeted future improvements and refinements to the model are ongoing. Specifically, in its current configuration, the benthic fluxes of nutrients and sediment oxygen demand were fixed as externally specified inputs. It is generally understood that parts of Puget Sound such as the southernmost regions of Hood Canal and parts of South Puget Sound have higher levels of benthic activity as a result of organic loads and could be a source of nutrients and pathogens (not included). The model predictions, particularly in the deeper waters of Puget Sound, are strongly dependent on the Pacific Ocean water quality (at the Neah Bay boundary in the Strait of Juan de Fuca) and the quality of inflow of water from Georgia Straits (affected correspondingly by the boundary near Johnstone Strait). The quality and quantity of inflow water from Georgia Strait boundary is a source of uncertainty and the model results are sensitive to specified concentrations at depth at the Strait of Juan de Fuca boundary.

The available data on phytoplankton community structure and primary production, including chlorophyll $a$ concentrations, are very limited in Puget Sound. This limits the ability to capture the influence of phytoplankton carbon on DO on short weekly or fortnightly timescales. We have used two species of algae (diatoms and dinoflagellates) to re-create the seasonal variation through spring and summer bloom peaks. However, without specific data on each algal type, the model relies on best professional judgment to adjust the phytoplankton succession. Similarly, zooplankton data were not available for this calibration effort. As a result, zooplanktons were not simulated explicitly, but the effect was incorporated in the form of predation rate, which is a function of algal biomass and temperature. Although a total of 99 wastewater point sources and the effect of the mass loading of nutrient and carbon from the point sources on DO kinetics were included, the resolution at each outfall is insufficient for use in near-field mixing zone analyses.

Despite these limitations, the model reproduces overall seasonal algal bloom dynamics and DO levels in Puget Sound resulting from exchanges with the Pacific Ocean and nutrient loads from natural and human sources within the basin. All deeper basins of Puget Sound show a 

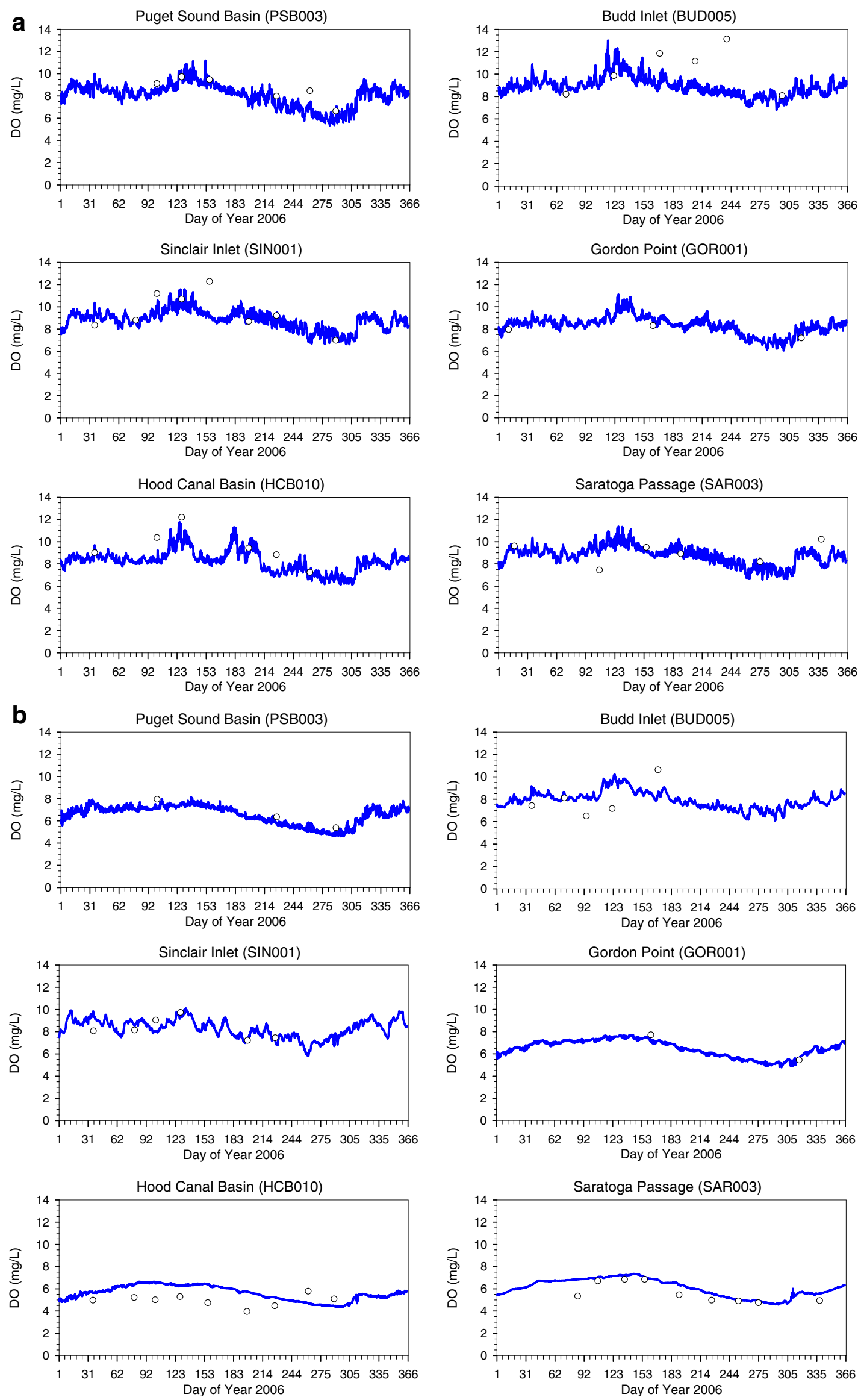
Fig. 11 a DO time history - comparison of measured surface data at selected stations in Puget Sound with model results for year 2006. b DO time history - comparison of measured bottom data at selected stations in Puget Sound with model results for year 2006

common biological behavior and response, which are different from the highly productive shallow subbasins. The fjordal subbasins within Puget Sound exhibit well-defined patterns that are consistent with classic fjord theory and are clearly distinguishable from the other basins. These differences appear to be strongly driven by the differences in fjordal hydrodynamics and circulation between the individual estuaries. Incorporation of all these types of estuaries into a single framework was challenging, but feasible using the approach and framework selected for this development. The overall model domain resolution was kept at a moderate level by design to facilitate efficient run times (a 1-year model run with 35 computational cores and 18 state variables requires about $24 \mathrm{~h}$ in real time using a previously computed hydrodynamic solu- tion). In addition to improving boundary conditions, higher lateral model resolution in shallow subbbasins, reduction in bathymetric smoothing, and improvement in inter-basin exchanges will further improve the ability of the model to simulate biogeochemical response in the Salish Sea.

Acknowledgments The development of this model for application to Puget Sound was funded through the U.S. Environmental Protection Agency Grant (EPA-R10-PS-1004) titled "Puget Sound Circulation and Dissolved Oxygen Model 2.0: Human Contributions and Climate Influences." This work would not have been possible without technical input and contributions from our current and former colleagues Dr. Taeyun Kim, Dr. Rochelle Labiosa, Dr. Zhaoqing Yang, and Dr. Taiping Wang. We also acknowledge our collaborators Karol Erickson from the Washington State Department of Ecology and Ben Cope from the U.S. Environmental Protection Agency for their encouragement and support.

Open Access This article is distributed under the terms of the Creative Commons Attribution License which permits any use, distribution, and reproduction in any medium, provided the original author(s) and the source are credited.

\section{Appendix}

A: Hydrodynamic model calibration error statistics for at selected locations in Puget Sound (2006)

Table A1 Model calibration error statistics for water surface elevation

MAE mean absolute error, RMSE root mean square error

Table A2 Model calibration error statistics for velocity

$M A E$ mean absolute error, RMSE root mean square error

\begin{tabular}{lcccc}
\hline Station & MAE $(\mathrm{m})$ & RMSE $(\mathrm{m})$ & RME $(\%)$ & Correlation $(R)$ \\
\hline Port Angeles & 0.26 & 0.33 & 8.88 & 0.92 \\
Friday Harbor & 0.17 & 0.22 & 5.77 & 0.97 \\
Cherry Point & 0.25 & 0.31 & 7.33 & 0.97 \\
Port Townsend & 0.28 & 0.35 & 8.93 & 0.95 \\
Seattle & 0.34 & 0.43 & 9.50 & 0.95 \\
Tacoma & 0.36 & 0.46 & 10.21 & 0.95 \\
Mean & 0.28 & 0.35 & 8.44 & 0.95 \\
\hline
\end{tabular}

\begin{tabular}{|c|c|c|c|c|c|c|c|c|c|}
\hline \multirow[t]{2}{*}{ Station } & \multicolumn{3}{|c|}{$\operatorname{MAE}(\mathrm{m} / \mathrm{s})$} & \multicolumn{3}{|c|}{$\operatorname{RMSE}(\mathrm{m} / \mathrm{s})$} & \multicolumn{3}{|c|}{ Correlation $(R)$} \\
\hline & Surface & Middle & Bottom & Surface & Middle & Bottom & Surface & Middle & Bottom \\
\hline $\begin{array}{l}\text { Pickering } \\
\text { Passage }\end{array}$ & 0.16 & 0.1 & 0.09 & 0.2 & 0.13 & 0.12 & 0.65 & 0.90 & 0.81 \\
\hline $\begin{array}{l}\text { Dana } \\
\text { Passage }\end{array}$ & 0.28 & 0.26 & 0.23 & 0.34 & 0.29 & 0.28 & 0.89 & 0.93 & 0.90 \\
\hline $\begin{array}{l}\text { Swinomish } \\
\text { Channel }\end{array}$ & 0.23 & 0.16 & 0.09 & 0.27 & 0.19 & 0.11 & 0.96 & 0.96 & 0.96 \\
\hline Skagit Bay & 0.23 & 0.16 & 0.17 & 0.28 & 0.19 & 0.2 & 0.82 & 0.90 & 0.88 \\
\hline Mean & 0.18 & & & 0.2 & & & 0.88 & & \\
\hline
\end{tabular}


Table A3 Model calibration error statistics for salinity and temperature
MAE mean absolute error, RMSE root mean square error

\begin{tabular}{|c|c|c|c|c|}
\hline \multirow[t]{2}{*}{ Station } & \multicolumn{2}{|l|}{ Salinity, ppt } & \multicolumn{2}{|c|}{ Temperature, ${ }^{\circ} \mathrm{C}$} \\
\hline & MAE (ppt) & RMSE (ppt) & $\operatorname{MAE}\left({ }^{\circ} \mathrm{C}\right)$ & $\operatorname{RMSE}\left({ }^{\circ} \mathrm{C}\right)$ \\
\hline Admiralty Inlet Entrance (ADM2) & 0.68 & 0.96 & 0.62 & 0.72 \\
\hline Admiralty Inlet North (ADM1) & 0.85 & 0.97 & 0.63 & 0.74 \\
\hline Admiralty Inlet South (ADM3) & 0.73 & 1.04 & 0.57 & 0.75 \\
\hline Puget Sound Main Basin (PSB) & 1.27 & 2.15 & 0.83 & 0.94 \\
\hline East Passage (EAP) & 0.79 & 1.19 & 0.8 & 0.89 \\
\hline Gordon Point (GOR1), South Sound & 0.81 & 1.09 & 1 & 1.11 \\
\hline Hood Canal (HCB003) & 0.74 & 0.88 & 0.8 & 1.13 \\
\hline Saratoga Passage (SAR003) & 0.71 & 1.08 & 0.89 & 1.12 \\
\hline Nisqually Reach (NSQ) & 0.64 & 0.74 & 1.08 & 1.18 \\
\hline Dana Passage (DNA) & 0.63 & 0.76 & 1.26 & 1.43 \\
\hline Mean & 0.78 & 1.09 & 0.85 & 1 \\
\hline
\end{tabular}

B: Hydrodynamic model calibration error statistics for at selected locations in Puget Sound (2006)

Table B1 Model calibration error statistics for Algal chlorophyll $a$

Output compared with discrete surface chlorophyll samples

RMSE root mean square error, Bias mean of paired differences (modeled-observed), SD standard deviation of paired differences (modeled-observed)

Table B2 Model calibration error statistics for dissolved oxygen (DO)

Output compared with $0.5 \mathrm{~m}$ binned Winkler-adjusted DO measurements from full water column CTD profiles

RMSE root mean square error, Bias mean of paired differences (modeled-observed), SD standard deviation of paired differences (modeled-observed)

\begin{tabular}{lllcrc}
\hline Region & Location & ID & RMSE $(\mu \mathrm{g} / \mathrm{L})$ & Bias $(\mu \mathrm{g} / \mathrm{L})$ & SD $(\mu \mathrm{g} / \mathrm{L})$ \\
\hline South & Dana Passage & DNA001 & 2.72 & -0.98 & 2.59 \\
South & Gordon Point & GOR001 & 1.76 & -0.72 & 1.62 \\
Central & Commencement Bay & CMB003 & 1.96 & 0.05 & 2.01 \\
Central & Sinclair Inlet & SIN001 & 5.11 & -2.44 & 4.63 \\
Central & West Point & PSB003 & 4.52 & -0.72 & 4.5 \\
Hood Canal & Hood Canal North & HCB010 & 8.95 & -3.27 & 8.61 \\
Whidbey Basin & Saratoga Passage & SAR003 & 4.97 & 0.49 & 5.08 \\
SJdF & Admiralty Inlet Entrance & ADM002 & 1.88 & 1.13 & 1.55 \\
Bellingham Bay & Bellingham Bay & BLL009 & 5.32 & 0.39 & 5.43 \\
& & Mean & 4.13 & -0.67 & 4.00 \\
\hline
\end{tabular}

\begin{tabular}{|c|c|c|c|c|c|}
\hline Region & Location & ID & $\begin{array}{l}\text { RMSE (mg/ } \\
\mathrm{L})\end{array}$ & $\begin{array}{l}\text { Bias (mg/ } \\
\mathrm{L})\end{array}$ & $\begin{array}{l}\mathrm{SD}(\mathrm{mg} / \\
\mathrm{L})\end{array}$ \\
\hline South & Dana Passage & $\begin{array}{r}\text { DNA001 } \\
\text { (SS03) }\end{array}$ & 1.14 & -0.43 & 1.05 \\
\hline South & Gordon Point & $\begin{array}{r}\text { GOR001 } \\
\text { (SS66) }\end{array}$ & 0.88 & -0.75 & 0.46 \\
\hline Central & Commencement Bay & CMB003 & 0.81 & -0.63 & 0.51 \\
\hline Central & Sinclair Inlet & SIN001 & 1.52 & -0.55 & 1.42 \\
\hline Central & West Point & PSB003 & 1.14 & -0.91 & 0.68 \\
\hline Hood Canal & Hood Canal North & НCB010 & 1.13 & 0.28 & 1.09 \\
\hline Whidbey Basin & Saratoga Passage & SAR003 & 0.86 & 0.21 & 0.83 \\
\hline SJdF & $\begin{array}{l}\text { Admiralty Inlet } \\
\text { Entrance }\end{array}$ & ADM002 & 1.42 & -0.94 & 1.06 \\
\hline \multirow{2}{*}{$\begin{array}{l}\text { Bellingham } \\
\text { Bay }\end{array}$} & Bellingham Bay & BLL009 & 1.25 & -0.71 & 1.03 \\
\hline & & Mean & 1.14 & -0.43 & 1.05 \\
\hline
\end{tabular}


Table B3 Model calibration error statistics for nitrate + nitrite $\left(\mathrm{NO}_{3}+\mathrm{NO}_{2}\right)$

Output compared with discrete $\mathrm{NO}_{3}+\mathrm{NO}_{2}$ samples

RMSE root mean square error, Bias mean of paired differences (modeled-observed), SD standard deviation of paired differences (modeled-observed)

\begin{tabular}{|c|c|c|c|c|c|}
\hline Region & Location & ID & $\begin{array}{l}\text { RMSE }(\mu \mathrm{mol} / \\
\mathrm{L})\end{array}$ & $\begin{array}{l}\text { Bias }(\mu \mathrm{mol} / \\
\mathrm{L})\end{array}$ & $\begin{array}{l}\mathrm{SD}(\mu \mathrm{mol} / \\
\mathrm{L})\end{array}$ \\
\hline South & Dana Passage & DNA001 & 7.14 & 4.29 & 5.71 \\
\hline South & Gordon Point & GOR001 & 3.57 & 2.86 & 2.86 \\
\hline Central & Commencement Bay & CMB003 & 3.57 & 0.71 & 3.57 \\
\hline Central & Sinclair Inlet & SIN001 & 8.57 & 6.43 & 5.71 \\
\hline Central & West Point & PSB003 & 4.29 & 1.43 & 3.57 \\
\hline Hood Canal & Hood Canal North & HCB010 & 7.86 & 3.57 & 7.14 \\
\hline Whidbey Basin & Saratoga Passage & SAR003 & 5.00 & 0.71 & 5.00 \\
\hline SJdF & $\begin{array}{l}\text { Admiralty Inlet } \\
\text { Entrance }\end{array}$ & ADM002 & 2.86 & 0.71 & 2.86 \\
\hline \multirow{2}{*}{$\begin{array}{l}\text { Bellingham } \\
\text { Bay }\end{array}$} & Bellingham Bay & BLL009 & 0.13 & 0.71 & 10.00 \\
\hline & & Mean & 4.78 & 2.38 & 5.16 \\
\hline
\end{tabular}

Table B4 Model calibration error statistics for phosphate $\left(\mathrm{PO}_{4}\right)$

Output compared with discrete $\mathrm{PO}_{4}$ samples

$R M S E$ root mean square error, Bias mean of paired differences (modeled-observed), SD standard deviation of paired differences (modeled-observed)

\begin{tabular}{|c|c|c|c|c|c|}
\hline Region & Location & ID & $\begin{array}{l}\text { RMSE }(\mu \mathrm{mol} / \\
\mathrm{L})\end{array}$ & $\begin{array}{l}\text { Bias }(\mu \mathrm{mol} / \\
\mathrm{L})\end{array}$ & $\begin{array}{l}\mathrm{SD}(\mu \mathrm{mol} / \\
\mathrm{L})\end{array}$ \\
\hline South & Dana Passage & $\begin{array}{r}\text { DNA001 } \\
\text { (SS03) }\end{array}$ & 0.32 & 0.323 & 0.32 \\
\hline South & Gordon Point & $\begin{array}{r}\text { GOR001 } \\
\text { (SS66) }\end{array}$ & 0.32 & 0.000 & 0.32 \\
\hline Central & Commencement Bay & CMB003 & 0.32 & 0.000 & 0.32 \\
\hline Central & Sinclair Inlet & SIN001 & 0.65 & 0.646 & 0.65 \\
\hline Central & West Point & PSB003 & 0.32 & 0.000 & 0.32 \\
\hline Hood Canal & Hood Canal North & НCB010 & 0.65 & 0.000 & 0.65 \\
\hline $\begin{array}{l}\text { Whidbey } \\
\text { Basin }\end{array}$ & Saratoga Passage & SAR003 & 0.65 & 0.000 & 0.65 \\
\hline SJdF & $\begin{array}{l}\text { Admiralty Inlet } \\
\text { Entrance }\end{array}$ & ADM002 & 0.32 & 0.323 & 0.32 \\
\hline \multirow{2}{*}{$\begin{array}{l}\text { Bellingham } \\
\text { Bay }\end{array}$} & Bellingham Bay & BLL009 & 0.65 & 0.32 & 0.65 \\
\hline & & Mean & 0.47 & 0.18 & 0.47 \\
\hline
\end{tabular}

\section{References}

Albertson SL, Erickson K, Newton JA, Pelletier G, Reynolds RA, Roberts ML (2002) South Puget Sound water quality study phase 1. Pub. no. 02-03-021. Washington Department of Ecology, Olympia

Babson AL, Kawase M, MacCready P (2006) Seasonal and interannual variability in the circulation of Puget Sound, Washington: a box model study. Atmos Ocean 44(1):29-45

Bahng B, Kawase M, Newton J, Devol A, Ruef W (2007) Numerical simulation of hypoxia in Hood Canal, USA. Proceedings of the Georgia Basin-Puget Sound Research Conference, March 26-29, 2007, Vancouver, British Columbia, Canada

Barnes CA, Collias EE (1958) Some considerations of oxygen utilization rates in Puget Sound. J Mar Res 17(1):68-80

Bernhard AE, Peele ER (1997) Nitrogen limitation of phytoplankton in a shallow embayment in northern Puget Sound. Estuaries 20:759-769
Bienfang PK, Harrison PJ (1984) Sinking-rate response of natural assemblages of temperate and subtropical phytoplankton to nutrient depletion. Mar Biol 83:293-300

Bowie GL, Mills WB, Porcella DB, Campbell CL, Pagenkopf JR, Rupp GL, Johnson KM, Chan PWH, Gherini SA, Chamberlin CE (1985) Rates, constants, and kinetics formulations in surface water quality modeling. EPA/600/3-85/040. Environmental Research Laboratory, Office of Research and Development, U.S Environmental Protection Agency, Athens

Brandes J, Devol AH (1995) Isotopic fractionation of oxygen and nitrogen in coastal marine sediments. Geochim Cosmochim Acta 61(9):1793-1801

Bunch BW, Cerco CF, Dorth MS, Johnson BH, Kim KW (2000) Hydrodynamic and water quality model of San Juan Bay estuary. Technical Report ERDC TR-00-1, U.S. Army Corps of Engineers, Vicksburg, Mississippi.

Cerco CF (2000) Chesapeake Bay eutrophication model. In: Hobbie JE (ed) Estuarine science: A synthetic approach tomodels, develop 
effective source controls, and decipher research and practice. Island Press, New York, pp 363-404

Cerco C, Cole T (1994) Three-dimensional eutrophication model of Chesapeake Bay. Technical Report EL-94-4, U.S. Army Corps of Engineers, Vicksburg, Mississippi

Cerco CF, Cole T (1995) User's guide to the CE-QUAL-ICM threedimensional eutrophication model, release version 1.0. EL-95-15. U.S. Army Corps of Engineers, Engineer Research and Development Center, Waterways Experiment Station, Vicksburg, Mississippi

Cerco CF, Bunch BW, Teeter AM, Dorth MS (2000) Water quality model of Florida Bay. Technical Report ERDC/EL TR-00-10, U.S. Army Corps of Engineers, Vicksburg, Mississippi

Cerco CF, Noel MR, Tillman DH (2004) A practical application of Droop nutrient kinetics (WR 1883). Water Res 38(20):4446-4454

Chen C, Liu H, Beardsley RC (2003) An unstructured, finite-volume, three-dimensional, primitive equation ocean model: application to coastal ocean and estuaries. J Atmos Ocean Tech 20:159-186

Cohn TA, Caulder DL, Gilroy EJ, Zynjuk LD, Summers RM (1992) The validity of a simple statistical model for estimating fluvial constituent loads: an empirical study involving nutrient loads entering Chesapeake Bay. Water Resour Res 28(9):2353-2363

Cokelet ED, Stewart RJ, Ebbesmeyer CC (1990) The annual mean transport in Puget Sound. NOAA Technical Memorandum ERL PMEL-92, Pacific Marine Environmental Laboratory, Seattle, Washington.

Cole TM and EM Buchak. 1995. CE-QUAL-W2: a two-dimensional, laterally averaged, hydrodynamic and water quality model, Version 2.0-User Manual. Instruction Report EL-95-1, U.S. Army Corps of Engineers, Engineer Research and Development Center, Waterways Experiment Station, Vicksburg, Mississippi

Connell L, Jacobs M (1998) Anatomy of a bloom: Heterosigma carterae in Puget Sound-1997. In: Puget Sound Research '98 Proceedings, Puget Sound Water Quality Action Team, Olympia, Washington

Ebbesmeyer CC, Barnes CA (1980) Control of a fjord basin's dynamics by tidal mixing in embracing sill zones. Estuar Coast Mar Sci $11: 311-330$

Eppley RW, Rogers JN, McCarthy JJ (1969) Half-saturation constants for uptake of nitrate and ammonium by marine phytoplankton. Limnol Oceanogr 14(6):912-920

Flater D (1996) A brief introduction to XTide. Linux J 32:51-57

Foreman MGG, Czajko P, Stucchi DJ, Guo M (2009) A finite volume model simulation for the Broughton Archipelago, Canada. Ocean Model 30(1):29-47

Friebertshauser MA, Duxbury AC (1972) A water budget study of Puget Sound and its subregions. Limnol Oceanogr 17(2):237e247

Geyer WR, Cannon GA (1982) Sill processes related to deep water renewal in a fjord. J Geophys Res 87(C10):7985-7996

Grundmanis VG, Murray JW (1977) Nitrification and denitrification in marine sediments from Puget Sound. Limnol Oceanogr 22:804-813

Hamilton P, Gunn JT, Cannon GA (1985) A box model of Puget Sound. Estuarine, Coastal and Shelf Science 20(6):673- 692

Harrison PJ, Mackas DL, Frost BW, MacDonald RW, Crecelius EA (1994) An assessment of nutrients, plankton, and some pollutants in the water column of Juan de Fuca Strait, Strait of Georgia, and Puget Sound, and their transboundary transport. In: Wilson RCH, Beamish RJ, Airkens F, Bell J (eds). Review of the marine environment and biota of Strait of Georgia, Puget Sound, and Juan de Fuca Strait: proceedings of the BC/Washington symposium on the marine environment, Jan 13 and 14, 1994. Can Tech Rep Fish Aquat Sci; 1994. pp. 138-72

Herndon J, Cochlan WP (2007) Nitrogen utilization by the raphidophyte Heterosigma akashiwo: growth and uptake kinetics in laboratory cultures. Harmful Algae 6:260-270
Hickey B, Banas NS (2003) Oceanography of the U.S. Pacific Northwest coastal ocean and estuaries with application to coastal ecology. Estuaries 26:010-1031

Horner RA, Postel JR, Halsban d-Lenk C, Pierson JJ, Pohnert G, Wichard T (2005) Winter-spring phytoplankton blooms in Dabob Bay, Washington. Prog Oceanogr 67(3-4):286-313

Jassby A, Platt T (1976) Mathematical formulation of the relationship between photosynthesis and light for phytoplankton. Limnol Oceanogr 21:40-547

Jickells TD (1998) Nutrient biogeochemistry of the Coastal Zone. Science 281:217-222

Khangaonkar T, Yang Z (2011) A high resolution hydrodynamic model of Puget Sound to support nearshore restoration feasibility analysis and design. Ecol Restor 29(1-2):173-184

Khangaonkar T, Yang Z, Kim T, Roberts M (2011) Tidally averaged circulation in Puget Sound sub-basins: comparison of historical data, analytical model, and numerical model. Estuar Coast Shelf S 93(4):305-319

Kim T, Khangaonkar T (2011) An offline unstructured biogeochemical model (UBM) for complex estuarine and coastal environments. (Accepted for publication) J Environmental Modeling and Software

Krembs (2011) Marine Water Quality Composite Index. Publication No. 11-03-018 (Draft), March Washington State Department of Ecology, Olympia

Lavelle JW, Cokelet ED, Cannon GA (1991) A model study of density intrusions into and circulation within a deep, silled estuaryPuget Sound. J Geophys Res - Oceans 96(C9):16779-16800

Li M, Gargett A, Denman K (1999) Seasonal and interannual variability of estuarine circulation in a box model of the Strait of Georgia and Juan de Fuca Strait. Atmos Ocean 37(1):1e19

Mackas DL, Harrison PJ (1997) Nitrogenous nutrient sources and sinks in the Juan de Fuca Strait/Strait of Georgia/Puget Sound Estuarine System. Estuar Coast Shelf S 44:1-21

McAllister CD (1970) Zooplankton ratios, phytoplankton mortality, and the estimation of marine production. In: Steele JH (ed), Marine Food Chains, International Council for the Exploration of the Sea, University of California Press, pp. 419-457

Mellor GL, Yamada T (1982) Development of a turbulence closure model for geophysical fluid problems. Rev Geophys 20(4):851-875

Mellor GL, Ezer T, Oey L-Y (1994) The pressure gradient conundrum of sigma coordinate ocean models. J Atmos Ocean Tech 11 (4):1126-1134

Mohamedali T, Roberts M, Sackmann BS, Kolosseus A (2011) Puget Sound dissolved oxygen model: nutrient load summary for 1999 2008. Publication no. 11-03-057, Washington State Department of Ecology, Olympia, Washington

Nairn BJ, Kawase M (2002) Comparison of observed circulation patterns and numerical model predictions in Puget Sound, WA. In: Droscher T (ed) Proceedings 2001 Puget Sound Research Conference. Puget Sound Water Quality Action Team, Olympia, p 9

Newton JA, Van Voorhis K (2002) Seasonal patterns and controlling factors of primary production in Puget Sound's central basin and Possession Sound. Publication no. 02-03-059, Washington State Department of Ecology, Lacey, Washington

Newton JA, Thomson AL, Eisner LB, Hannach GA, Albertson SL. 1995. Dissolved oxygen concentrations in Hood Canal: are conditions different than forty years ago? In: Puget Sound Research ' 95 Proceedings, Puget Sound Water Quality Authority, Olympia, Washington, pp. 1002-1008

Newton JA, Edie M, Summers J. 1998. Primary productivity in Budd Inlet: seasonal patterns of variation and controlling factors. In: Puget Sound Research '98 Proceedings, Puget Sound Action Team, Olympia, Washington, pp. 132-151

Newton J, Bassin C, Devol A, Kawase M, Ruef W, Warrner M, Hannafious D, Rose R (2007) Hypoxia in Hood Canala: an overview of status and contributing factors. Presented to the 
2007 Georgia Basin Puget Sound Research Conference, March 26-29, 2007, Vancouver, British Columbia, Canada

Odum EP (1971) Fundamentals of ecology, 3rd edn. W. B. Saunders Co., Philadelphia

Pamatmat MM (1971) Oxygen consumption of the seabed. 6. Seasonal cycle of chemical oxidation and respiration in Puget Sound. Int Revue ges Hydrobiol 56:769-793

Rensel JEJ (2007) Fish kills from the harmful alga Heterosigma akashiwo in Puget Sound: recent blooms and review. Rensel Associates Aquatic Sciences, Arlington

Roberts M, Bos J, Albertson S (2008) South Puget sound dissolved oxygen study interim data report. Publication no. 08-03-037, Washington State Department of Ecology, Olympia, Washington

Roberts M, Albertson S, Ahmed A, Pelletier G (2009) South Puget Sound dissolved oxygen study - south and central Puget Sound water circulation model development and calibration. Publication-External Review Draft-10-15-09, Washington State Department of Ecology, Olympia, Washington

Ruef W, Devol A, Emerson S, Dunne J, Newton J, Reynolds R, Lynton J (2003) In situ and remote monitoring of water quality in South Puget Sound: The ORCA time-series. Proceedings of the 2003 Georgia Basin-Puget Sound Research Conference, Vancouver, BC March 31-April 3, 2003
Smagorinsky J (1963) General circulation experiments with the primitive equations. I. The basic experiment. Mon Weather Rev 91(3):99-164

Sutherland DA, MacCready P, Banas NS, Smedstad LF (2011) A model study of the Salish Sea estuarine circulation. J Phys Oceanog 41:125-1143

Thom RM, Albright RG (1990) Dynamics of benthic vegetation standing-stock, irradiance, and water properties in central Puget Sound. Mar Biol 104:129-141

Thom RM, Copping A, Albright RG (1988) Nearshore primary productivity in central Puget Sound: a case for nutrient limitation in the nearshore systems of Puget Sound. In: Proceedings of First Annual Meeting on Puget Sound Research Volume 2, Seattle, Washington (March 18-19, 1988)

Tillman DH, Cerco CF, Noel MR, Martin JL, Hamrick J (2004) Threedimensional eutrophication model of the lower St. Johns River, Florida. Technical Report ERDC/El TR-04 13, U.S. Army Engineer Waterways Experiment Station, Vicksburg, Mississippi

Winter DF, Banse K, Anderson GC (1975) The dynamics of phytoplankton blooms in Puget Sound, a fjord in the northwestern United States. Mar Biol 29:139-176

Yang Z, Khangaonkar T (2010) Multi-scale modeling of Puget Sound using an unstructured-grid coastal ocean model: from tide flats to estuaries and coastal waters. Ocean Dyn 60(6):1621-1637 